\title{
Modulations of Cardiac Functions and Pathogenesis by Reactive Oxygen Species and Natural Antioxidants
}

\author{
Sun-Hee Woo ${ }^{1, *}$, Joon-Chul Kim ${ }^{2} \mathbb{D}$, Nipa Eslenur ${ }^{1}$, Tran Nguyet Trinh ${ }^{1}\left[\right.$ and Long Nguyen Hoàng Do ${ }^{1}$ \\ 1 College of Pharmacy, Chungnam National University, 99 Daehak-ro, Yuseong-gu, Daejeon 34134, Korea; \\ eslenur45pharm@gmail.com (N.E.); tranctu1994@gmail.com (T.N.T.); dnhlong17@gmail.com (L.N.H.D.) \\ 2 NEXEL Co., 8F 55 Magokdong-ro, Gangseo-gu, Seoul 07802, Korea; jckim@nexel.co.kr \\ * Correspondence: shwoo@cnu.ac.kr; Tel.: +82-42-821-5924; Fax: +82-42-823-6566
}

Citation: Woo, S.-H.; Kim, J.-C.; Eslenur, N.; Trinh, T.N.; Do, L.N.H. Modulations of Cardiac Functions and Pathogenesis by Reactive Oxygen Species and Natural Antioxidants. Antioxidants 2021, 10, 760. https:// doi.org/10.3390/antiox10050760

Academic Editor: Ángel Luis Ortega

Received: 11 April 2021

Accepted: 8 May 2021

Published: 11 May 2021

Publisher's Note: MDPI stays neutral with regard to jurisdictional claims in published maps and institutional affiliations.

Copyright: (c) 2021 by the authors. Licensee MDPI, Basel, Switzerland. This article is an open access article distributed under the terms and conditions of the Creative Commons Attribution (CC BY) license (https:// creativecommons.org/licenses/by/ $4.0 /)$.
Abstract: Homeostasis in the level of reactive oxygen species (ROS) in cardiac myocytes plays a critical role in regulating their physiological functions. Disturbance of balance between generation and removal of ROS is a major cause of cardiac myocyte remodeling, dysfunction, and failure. Cardiac myocytes possess several ROS-producing pathways, such as mitochondrial electron transport chain, NADPH oxidases, and nitric oxide synthases, and have endogenous antioxidation mechanisms. Cardiac $\mathrm{Ca}^{2+}$-signaling toolkit proteins, as well as mitochondrial functions, are largely modulated by ROS under physiological and pathological conditions, thereby producing alterations in contraction, membrane conductivity, cell metabolism and cell growth and death. Mechanical stresses under hypertension, post-myocardial infarction, heart failure, and valve diseases are the main causes for stress-induced cardiac remodeling and functional failure, which are associated with ROS-induced pathogenesis. Experimental evidence demonstrates that many cardioprotective natural antioxidants, enriched in foods or herbs, exert beneficial effects on cardiac functions $\left(\mathrm{Ca}^{2+}\right.$ signal, contractility and rhythm), myocytes remodeling, inflammation and death in pathological hearts. The review may provide knowledge and insight into the modulation of cardiac pathogenesis by ROS and natural antioxidants.

Keywords: cardiac $\mathrm{Ca}^{2+}$ signaling; ROS; natural antioxidants; mitochondria; cardiac pathogenesis cardioprotective

\section{Introduction}

Antioxidants are substances that can prevent or slow damage to cells caused by free radicals, unstable molecules that the body produces as a reaction to environmental changes and other stresses. Representative free radicals, endogenously produced by our body, are reactive oxygen species (ROS) and reactive nitrogen species (RNS). A balance between free radicals and antioxidants is necessary for normal physiological function. An unbalanced increase of free radical level adversely alters lipid bilayers, proteins, and DNA and causes many human diseases, including cardiac diseases. Recent evidence additionally shows that ROS and RNS act as ubiquitous intracellular messengers and conduct redox signaling [1-4]. The present review provides an overview of ROS regulations in cardiac myocytes and their effects on $\mathrm{Ca}^{2+}$-signaling proteins and ion transporters/channels that are critical for cardiac rhythm and contraction. In addition, we describe alterations of ROS regulatory mechanisms and their impact on cardiac myocytes under cardiac diseases and natural antioxidants in foods and herbs, which modulate cardiac muscle functions, its pathological remodeling and apoptosis. This review may provide an insight on their potential use to prevent and treat heart failure (HF), ischemia-reperfusion (I-R)-mediated cardiac cell apoptosis, hypertrophic growth and arrhythmias. 


\section{Oxidative Stress and Endogenous Antioxidants in Cardiac Muscle}

\subsection{Cardiac Oxidative Stress and Its Role in Ischemic Injury}

ROS are a group of chemical species that comprise at least one oxygen atom in each molecule and display stronger reactivity than molecular oxygen. ROS are classified into free radicals with an unpaired electron (e.g., $\mathrm{O}_{2}{ }^{\bullet-}$ and $\mathrm{OH}^{\bullet}$ ) and non-radical derivatives (e.g., $\mathrm{H}_{2} \mathrm{O}_{2}$ ) [5]. The representative $\mathrm{RNS}$ is ${ }^{\bullet} \mathrm{NO}$ that plays a central role in cardiovascular signaling. Homeostasis of ROS level is required to establish the redox balance of the cell. Excess ROS or fewer antioxidants cause oxidative stress and harmful effects. Potential sources of ROS include the mitochondrial electron transport chain, xanthine oxidase, cytochrome P450-based enzymes and NADPH oxidase (NOX) [5,6]. The bulk of ATP in cardiac cells is generated by oxidative metabolism, which is the sequential passage of electrons from high to low redox potentials down the electron transport chain composed of complexes I to IV [6]. This process results in the active pumping of $\mathrm{H}^{+}$out of the mitochondrial matrix into the intermembranous space. Electrochemical gradient across the inner mitochondrial membrane is then established by the translocation of a proton from the intermembrane space through the Fo/F1 ATPase back into the mitochondrial matrix. This proton translocation is coupled to the phosphorylation of ADP to generate ATP [6]. During this process, $\mathrm{O}_{2}{ }^{\bullet-}$ are produced via complexes I and III.

The progression of HF, as well as its complications, involves significant mitochondrial remodeling, including $\mathrm{Ca}^{2+}$ regulation, ROS or RNS generation, and energy production [6-9]. In HF, subpopulations of mitochondria around the cell periphery are primarily affected, while interfibrillar mitochondria are less affected [10]. Under pathological conditions, ROS can trigger a burst of ROS production by mitochondria that can lead to apoptotic cell death and inflammatory response. For example, during reperfusion of the ischemic heart, a burst of ROS formation occurs [11-13]. Extracellular stimuli, such as stretch, shear stress and angiotensin II (ANG II), often produce $\mathrm{O}_{2}{ }^{\bullet-}$ via a membrane-associated NOX [14-17]. NOX family has seven members, NOX1, NOX2, NOX3, NOX4, NOx5, dual oxidase 1 and dual oxidase 2. However, only the NOX1, NOX2, and NOX4 isoforms are expressed in the heart, NOX2 being the predominant isoform in the adult cardiac myocytes [18]. NOX2 is localized in the t-tubules of cardiac muscles, which makes it an important regulator of $\mathrm{Ca}^{2+}$ signaling at the dyads [19]. It is well-recognized that a higher level of ROS causes oxidative stress in ANG II-associated cardiovascular diseases through activation of NOXs [16,17], mitochondrial dysfunction [20-23], inflammation [23-27] and the decrease of endogenous antioxidant enzymes [28,29]. Nitrogen oxide synthase (NOS) also contributes to ANG II-related pathological conditions, such as hypertension, atherosclerosis, and diabetes [30] and to stretch signaling in cardiac myocytes [31].

ROS plays a significant role in the pathogenesis of myocardial infarction (MI) and post-MI remodeling in mice [32]. The ROS-mediated nuclear factor kappa-light-chainenhancer of activated B cells (NF- $\mathrm{kB}$ ) activation can trigger inflammation and damage through upregulating tumor necrosis factor- $\alpha$ (TNF- $\alpha$ ), Bcl-2-associated $X$ protein (Bax) and transforming growth factor $\beta 1$ (TGF- $\beta 1$ ) [33]. NOX2 protein levels as well as NF- $\mathrm{kB}$ activity were elevated in cardiac myocytes after acute $\mathrm{MI}$ in the infracted area [33,34], supporting that NF- $\mathrm{KB}$ is involved in the downstream pathway of ROS. This mechanism may lead to cardiac remodeling. Under myocardial injury, Toll-like receptor 4 (TLR4) is activated, which mediates the inflammatory response [35]. TLR-4 activation requires complex formation with myeloid differentiation protein 2 (MD2). The complex engages with the myeloid differentiation factor 88 adaptor protein (MyD88), which triggers receptor complex interaction with TNF receptor-associated factor 6 (TRAF6) and transforming growth factor-activated kinase 1 (TAK1) [36]. This signaling results in the downregulation of the inhibitor of NF- $\mathrm{kB}$, which further triggers the NF- $\mathrm{kB}$ to induce many inflammation mediators [37]. Evidence also suggests that I-R injury in the heart involves necroptosis, a form of programmed necrosis that can be observed downstream of death receptor and pattern recognition receptor signaling under a certain context and triggers inflammatory responses. Necroptosis is known to be triggered by activation of the receptor-interacting protein ki- 
nases (RIPK) [38]. Zhu et al. [39] have shown that the RIPK3 is induced in cardiomyocytes with lipopolysaccharide and $\mathrm{H}_{2} \mathrm{O}_{2}$ treatment and in I-R-injury. The induced-RIPK 3 representing endoplasmic reticulum (ER) stress leads to cardiomyocyte necroptosis through the increase of intracellular $\mathrm{Ca}^{2+}$ level and xanthine oxidase expression. Under these conditions, xanthine oxidase increases cellular ROS and involves mitochondrial permeability transition pore (mPTP) opening [39].

\subsection{Antioxidant Defense Systems}

Intracellular ROS levels are held in check by an intricate array of antioxidant defense systems. Impairment in these defenses and ROS scavenging can also lead to cardiac dysfunction [31,40-45]. There are enzymatic antioxidants and a nonenzymatic protection system. The enzymes include catalase, glutathione peroxidase (GSHPx), superoxide dismutase (SOD), and glutaredoxins (Grxs); nonenzymatic antioxidants include vitamins $\mathrm{E}$ and $\mathrm{C}, \beta$-carotene, ubiquinone, lipoic acid, urate, and reduced glutathione (GSH) [46-48]. GSH acts as a scavenger of electrophilic and oxidant species either in a direct way or through enzymatic catalysis. GSH is the cosubstrate of GSHPx and allows the reduction of peroxides and the production of GSSG [49]. The GSHPx enzyme is highly expressed in the cytosolic and mitochondrial compartments and is an important protection mechanism in the heart [49]. There are GSH-dependent oxidoreductases that can catalyze S-glutathionylation and deglutathionylation of proteins to defend $\mathrm{SH}$ groups from oxidation and restore functionally active thiols [50]. The thioredoxin (Trx) system composed of NADPH, thioredoxin reductase (TrxR), and Trx, can provide electrons to thiol-dependent peroxidases (peroxiredoxins) to remove ROS [51]. Peroxiredoxins, placed in different cellular compartments, act as molecular chaperones and phospholipase A2 [52]. Many of these antioxidation pathways are regulated by the transcription factor nuclear factor (erythroid-derived 2)-like 2 (NFE2L2), known as Nrf2 [53,54]. Therefore, Nrf2 exhibits many merits for tissue protection. Under normal conditions, Kelch-like ECH-associated protein 1 (KEAP1) promotes ubiquitination and eventual degradation of Nrf2 [55], while under conditions where the Nrf2-dependent cell defense mechanism is activated, Nrf2 is released from Keap1 and translocates to the nucleus where it binds to conserved antioxidant response element (ARE) sequence, which is followed by induction of expression of an array of cytoprotective gene products, including NAD(P)H quinone oxidoreductase, heme oxygenase-1 (HO-1), GSTs, and glutamate-cysteine ligase catalytic subunit [53,54].

$\mathrm{HO}-1$, in particular, can be induced by numerous stress conditions [56], and thus HO-1 induction is thought to be valuable as a pharmacological target. Many studies have demonstrated the role of HO-1 as an endogenous defense mechanism against cellular injury. The beneficial effect of HO-1 induction on oxidative stress or inflammation is associated with catalyzing the rate-limiting step in the degradation of heme group with its products, ferrous iron $\left(\mathrm{Fe}^{2+}\right)$, carbon monoxide (CO), and biliverdin, which is converted to bilirubin by the biliverdin reductase [57-61]. Excess heme contributes to free radical formation and increases cell damage due to its oxidative and inflammatory properties [62]. It is shown that biliverdin and bilirubin efficiently scavenge chemically generated peroxyl radicals at micromolar concentrations and decrease the peroxidation of low-density lipoproteins in vitro [63-65]. Intracellular CO alleviates oxidative damage by modulating mitochondrial function [66].

Pyruvate (2-oxopropanoate), a natural aliphatic carbohydrate produced in cytosol by glycolysis or lactate oxidation, has the capacity to enhance NADPH production and contributes to the glutathione redox state. In fact, this effect increases sarcoplasmic reticulum (SR) $\mathrm{Ca}^{2+}$ release [40]. It also has a beneficial effect to regenerate $\beta$-adrenergic signaling of ischemically stunned myocardium [40]. It is also known that pyruvate suppresses inflammation in the post-ischemic myocardium by decreasing $\mathrm{Ca}^{2+}$ dysregulation and oxidative stress [40]. It has been suggested that infusion of highly concentrated pyruvate solutions improves cardiac mechanical performance and protects the myocardium from ischemic injury [40]. 


\section{Regulation of Cardiac $\mathrm{Ca}^{2+}$ Signaling by Mitochondria and ROS in Health and Disease}

\subsection{Interaction between Cytosolic $\mathrm{Ca}^{2+}$ Signal and Mitochondria}

Contraction of cardiac myocytes is elicited by a transient increase in intracellular $\mathrm{Ca}^{2+}$ upon action potential firing. This $\mathrm{Ca}^{2+}$ increase is caused by a sequence of events ("excitation-contraction coupling") that includes L-type $\mathrm{Ca}^{2+}$ current $\left(\mathrm{I}_{\mathrm{Ca}}\right)$-gated opening of $\mathrm{Ca}^{2+}$ release channels (ryanodine receptors, RyRs) and the release of $\mathrm{Ca}^{2+}$ from the SR [67-70]. Laser scanning confocal microscopy has revealed the presence of focal $\mathrm{Ca}^{2+}$ release events from RyR clusters in cardiac myocytes (" $\mathrm{Ca}^{2+}$ sparks"). The $\mathrm{Ca}^{2+}$ sparks are independent of $\mathrm{I}_{\mathrm{Ca}}$ and voltage and represent unitary properties [71-73], indicating that they represent the elementary $\mathrm{Ca}^{2+}$ releases for cytosolic $\mathrm{Ca}^{2+}$ increase on depolarizations in cardiac myocytes [71-75]. Cytosolic $\mathrm{Ca}^{2+}$ is then removed from the cytosol via the SR $\mathrm{Ca}^{2+}$-ATPase pump (SERCA2) and sarcolemmal $\mathrm{Na}^{+}-\mathrm{Ca}^{2+}$ exchanger, and sarcolemmal $\mathrm{Ca}^{2+}$ pump [76,77].

A large fraction of cell volume ( $\sim 35 \%)$ in cardiac myocytes is occupied by mitochondria [78]. Mitochondria control cellular energy status by regulating $\mathrm{O}_{2}$-consuming ATP production. Mitochondrial ATP production allows cardiac contractile function and active transport via the $\mathrm{Na}^{+}-\mathrm{K}^{+}$pump and SR $\mathrm{Ca}^{2+}$ pump. These active transporters are essential for maintaining ionic gradients for $\mathrm{Na}^{+}, \mathrm{Ca}^{2+}$ and $\mathrm{K}^{+}$through the cell membrane and organelle membrane. Appropriate $\mathrm{Ca}^{2+}$ handling is also essential in the mitochondrial oxidative phosphorylation, redox balance [79] and for the production of optimal levels of ROS [6] and RNS [80]. However, mitochondrial $\mathrm{Ca}^{2+}$ uptake during an action potential has been thought to be very small (about $1 \%$ ) in ventricular myocytes [81,82]. Nevertheless, a small level of $\mathrm{Ca}^{2+}$ taken up by the mitochondria is thought to effectively regulate the oxidative phosphorylation by activating several key enzymes, such as pyruvate dehydrogenase phosphatase, isocitrate dehydrogenase, and $\alpha$-ketoglutarate dehydrogenase involved in ATP production in the mitochondrial matrix $[83,84]$. However, both increased and reduced mitochondrial $\mathrm{Ca}^{2+}$ levels have been associated with mitochondrial dysfunction [7].

The kinetics of mitochondrial $\mathrm{Ca}^{2+}$ uptake during action potential and how much mitochondria contribute to $\mathrm{Ca}^{2+}$ signaling are controversial [85]. However, these organelles likely interact with each other in the microdomains in the cardiac myocytes because mitochondria are closely localized to the SR membrane and myofibrils [86,87]. The outer membrane of mitochondria is known to be localized at $37-270 \mathrm{~nm}$ away from the SR RyRs [86]. Mathematical modeling has shown that the concentration of $\mathrm{Ca}^{2+}\left(\left[\mathrm{Ca}^{2+}\right]\right)$ in the narrow space between the mitochondria and SR could reach $10-300 \mathrm{nM}$ when $\left[\mathrm{Ca}^{2+}\right]$ reach $1-2 \mu \mathrm{M}$ on depolarization $[88,89]$. Recent experimental evidence supports the role of mitochondrial $\mathrm{Ca}^{2+}$ handling in the microdomains of cardiac myocytes [88-91]. The outer mitochondrial membrane does not have much selectivity for ionic movements. However, the voltage-dependent anion channel (VDAC) 2 in the outer mitochondrial membrane seems to contribute to the decay of $\mathrm{Ca}^{2+}$ sparks in the vicinity of RyRs and restrict $\mathrm{Ca}^{2+}$ spark expansion in atrial cells under resting conditions [91]. Interestingly, it has been reported that in atrial myocytes lacking transverse $(\mathrm{T})$-tubules, that peripheral mitochondria and VDAC are involved in regulating $\mathrm{Ca}^{2+}$ transients [92]. The level of $\mathrm{Ca}^{2+}$ in the space between mitochondria and SR seems to be enough to drive mitochondrial $\mathrm{Ca}^{2+}$ uptake through the inner mitochondrial membrane transporter or channels [85]. A major mechanism for $\mathrm{Ca}^{2+}$ transport across the mitochondrial inner membrane is known as mitochondrial $\mathrm{Ca}^{2+}$ uniporter [6]. Experimental evidence supports that local $\mathrm{Ca}^{2+}$ releases (sparks) may activate the low-affinity $\mathrm{Ca}^{2+}$ uptake in adjacent mitochondria [90] and thereby showing local mitochondrial matrix $\mathrm{Ca}^{2+}$ signals (" $\mathrm{Ca}^{2+}$ marks") [90]. In addition, the size and duration of $\mathrm{Ca}^{2+}$ sparks become bigger when the inner mitochondrial $\mathrm{Ca}^{2+}$ uptake is inhibited [90]. $\mathrm{Ca}^{2+}$ efflux from cardiac mitochondria occurs via the $\mathrm{Na}^{+}-\mathrm{Ca}^{2+}$ exchange (NCXL) [93]. Mitochondrial $\mathrm{Na}^{+}-\mathrm{Ca}^{2+}$ exchange has been shown to regulate mitochondrial $\mathrm{Ca}^{2+}$ levels and to connect mitochondrial $\mathrm{Ca}^{2+}$ to intracellular $\mathrm{Na}^{+}$. Therefore, 
increased cytosolic $\mathrm{Na}^{+}$concentration that occurs during hypertrophy and heart failure is known to lead to altered redox and metabolism.

\subsection{Altered $\mathrm{Ca}^{2+}$-Signaling Proteins by ROS and Their Pathological Significance}

Because of the high-energy demands of the heart, mutations in genes that encode electron transport chain proteins are associated with developing cardiomyopathy [94-96]. In addition, it is not surprising that impairment in the electron transport chain altered ATP production with subsequent dysregulations of intracellular $\mathrm{Ca}^{2+}$ and increased ROS generation, as well as redox unbalance $[97,98]$. Cardiac failure, ischemia, and arrhythmia are frequently associated with energy decrease and mitochondrial dysfunction [10,99]. Under pathological conditions of high cytosolic $\mathrm{Ca}^{2+}$, mitochondria are capable of taking up large amounts of $\mathrm{Ca}^{2+}$, which leads to the opening of the MPTP, a large conductance channel in the inner mitochondrial membrane [100]. The sustained opening of this transition pore is a trigger for cell death [101]. Then, what could be the cellular and molecular basis for ROS-mediated deteriorations of cardiac $\mathrm{Ca}^{2+}$ signaling?

In cardiac myocytes, action potential triggers L-type $\mathrm{Ca}^{2+}$ channel opening and initiates $\mathrm{Ca}^{2+}$ signaling (see above). The pore-forming subunit $\alpha_{1 \mathrm{C}}$ of the L-type $\mathrm{Ca}^{2+}$ channel contains more than 10 cysteine residues, which can undergo redox modification [102]. Thiol oxidizing agents are known to decrease the $\mathrm{I}_{\mathrm{Ca}}[103,104]$, although there are controversies in the effects of different oxidizing agents on the current in different species [105]. NO enhances $\mathrm{I}_{\mathrm{Ca}}$ redox-dependently or indirectly inhibits its cGMP-dependently [105].

$\mathrm{Ca}^{2+}$ leak through the RyR2 and $\mathrm{Ca}^{2+}$ wave under resting conditions increase in cardiac myocytes from HF and atrial fibrillation patients [106,107]. Using murine models are harboring RyR2 mutation that renders the channel leaky (RyR2-S2808D) and a model with RyR2 channels protected against leak (RyR2-S2808A), Santulli et al. [7] have demonstrated RyR2-mediated SR Ca ${ }^{2+}$ leak is associated with increased mitochondrial $\mathrm{Ca}^{2+}$ and ROS production, and that constitutive cardiac SR Ca ${ }^{2+}$ leak via RyR2 results in dysmorphic and malfunctioning mitochondria. In this regard, increasing evidence has demonstrated that cardiac RyRs also act as a cellular redox sensor because they have rich free thiol groups in their structure (364 cysteine residues in homotetramer, 21 of which are free on each subunit) [108-110]. Oxidation of the free thiols has been thought to activate RyRs in vitro and in situ, and their reductions suppress RyR activity [111-114]. Treatment of SOD or reducing agents and inhibition of the Complex III in the electron transport chain decrease not only the cytosolic ROS level but also $\mathrm{Ca}^{2+}$ spark occurrence in cardiac myocytes [111]. This indicates that basal ROS production and redox balance are responsible for a significant portion of the spontaneous $\mathrm{Ca}^{2+}$ spark activity. Application of $\mathrm{H}_{2} \mathrm{O}_{2}$ exogenously at the concentrations of 50-100 $\mu \mathrm{M}$ markedly enhances $\mathrm{Ca}^{2+}$ sparks $[115,116]$. At the concentrations of $200 \mu \mathrm{M}-1 \mathrm{mM}$ exogenous $\mathrm{H}_{2} \mathrm{O}_{2}$ application increased $\mathrm{Ca}^{2+}$ sparks and $\mathrm{Ca}^{2+}$ transients transiently for 1-3 min, which were followed by suppressing the local and global $\mathrm{Ca}^{2+}$ releases in cardiac myocytes [26,117]. Introduction of superoxide by activating xanthine oxidase also biphasically enhance $\mathrm{Ca}^{2+}$ spark activity for several min, such that they only transiently enhanced spark occurrence in cardiac myocytes $[117,118]$.

Inositol 1,4,5-trisphosphate receptor $\left(\mathrm{IP}_{3} \mathrm{R}\right)$, another $\mathrm{Ca}^{2+}$ release channel on the $\mathrm{SR}$ membrane, is thought to modulate $\mathrm{Ca}^{2+}$ signaling, although the density of $\mathrm{IP}_{3} \mathrm{Rs}$ is much lower than that of RyR2 in cardiac myocytes. In atrial myocytes, they significantly contribute to $\mathrm{Ca}^{2+}$ signaling regulation and arrhythmias [118-120]. It has been reported only in other cell types, such as hepatocytes and smooth muscle cells, or in vitro system, that oxidizing agents (e.g., thimerosal or oxidized glutathione) stimulate the $\mathrm{IP}_{3}$-mediated $\mathrm{Ca}^{2+}$ flux $[121,122]$. It has been shown that cardiac-specific deletion of $\mathrm{IP}_{3} \mathrm{R} 2$ had no major effect on mitochondrial fitness in HF [7].

$\mathrm{Ca}^{2+}$ sequestration by SERCA2a in the SR membrane plays a major role in the relaxation of cardiac myocytes. SERCA pump contains 25 cysteine residues, but only 1 or 2 are essential for enzyme action [123]. In contrast to the RyR, thiol oxidizing agents inhibit pump activity, whereas reducing agents protect SERCA from this inhibition [124]. $\mathrm{H}_{2} \mathrm{O}_{2}$ 
and hydroxyl radicals inactivate cardiac SERCA by interfering with the ATP-binding site on the SERCA [125]. ROS may also inhibit SERCA activity by peroxidation of membrane phospholipids [124]. NO does not appear to alter SERCA activity by $S$-nitrosylation of cysteine residues [126].

The $\mathrm{Na}^{+}-\mathrm{Ca}^{2+}$ exchanger 1, another major pathway of $\mathrm{Ca}^{2+}$ removal and homeostasis in cardiac myocytes, consists of 9 transmembrane domains. Disulfide bonds between cysteine residues of different domains of a $\mathrm{Na}^{+}-\mathrm{Ca}^{2+}$ exchanger is thought to be important for its function [127]. Superoxide produced by xanthine/xanthine oxidase reaction, but not by $\mathrm{H}_{2} \mathrm{O}_{2}$ and $\mathrm{HOCl}$, enhanced $\mathrm{Na}^{+}-\mathrm{Ca}^{2+}$ exchange-mediated $\mathrm{Ca}^{2+}$ fluxes [128]. ROS burst during reperfusion of the ischemic heart may enhance $\mathrm{Ca}^{2+}$ influx mode of $\mathrm{Na}^{+}-\mathrm{Ca}^{2+}$ exchange by an increase of intracellular $\mathrm{Na}^{+}$, resulting in $\mathrm{Ca}^{2+}$ overload.

Mitochondrial uncoupling using carbonyl cyanide m-chlorophenyl hydrazone (CCCP) or carbonyl cyanide 4-(trifluoromethoxy)phenylhydrazone (FCCP) that disrupt mitochondrial inner membrane potential and mimics ischemic conditions depolarizes the mitochondrial transmembrane potential, thereby inducing reduced $\mathrm{Ca}^{2+}$ uptake through the inner mitochondrial $\mathrm{Ca}^{2+}$ uniporter $[129,130]$. This is caused by the removal of the electrical gradient for $\mathrm{Ca}^{2+}$ uptake through the mitochondrial membrane. This mitochondrial upcoupling reduces action potential-induced $\mathrm{Ca}^{2+}$ transients $[131,132]$ and $\mathrm{SR} \mathrm{Ca}^{2+}$-loading, which results in cytosolic $\mathrm{Ca}^{2+}$ increase at diastole and the increased propensity of spontaneous $\mathrm{Ca}^{2+}$ waves [132]. It has been shown using confocal measurement with Mg-fluo-4 that intracellular ATP level decreases under such mitochondrial uncoupling [132]. In addition, $\mathrm{I}_{\mathrm{Ca}}$ has been inhibited by FCCP [132]. These responses can explain mitochondrial uncoupling-mediated $\mathrm{Ca}^{2+}$ transient decease as well as lower $\mathrm{SR} \mathrm{Ca}^{2+}$-loading.

\section{Roles of ROS in Cardiac Mechanical Stress Response and Pathogenesis}

Changes in the mechanical environment of the heart, caused by each cardiac cycle, alter cardiac excitation and contraction $[133,134]$. Such mechanical forces in the heart include preload, afterload and shear stress. Increased preload enhances cardiac contractility by Frank-Starling's law under physiological conditions [133], but high preload makes cardiac cells be largely stretched. Cardiac chambers become enlarged and dilated in HF, valve diseases, and chronic hypertension. Therefore, the stretch stimulus is implicated in developing such diseases. The responses of cardiac myocytes to stretch, including the stimulation of stretch-activated ion channels, have been well documented [135-137] and are thought to be an important cellular basis for cardiac remodeling and arrhythmogenesis under congestive HF [134]. The stretch-dependent changes in the cardiac contraction force have biphasic properties: first, a rapid and larger increase in force, and second, a slow increase in force $[138,139]$. Stretching of the ventricle and atrium is accompanied by increases in $\mathrm{Ca}^{2+}$ transient amplitude [140-142]. Stretch-induced augmentation of $\mathrm{Ca}^{2+}$ transients may result from enhanced unitary $\mathrm{Ca}^{2+}$ releases in ventricular myocytes. Stretch is known to activate NOX2 and endothelial isoform of NO synthase (eNOS) activity in the ventricular cells to produce ROS, thereby increasing $\mathrm{Ca}^{2+}$ spark occurrences $[14,31]$. Stretchinduced eNOS activation is known to occur via phosphatidylinositol-3-OH kinase (PI(3)K)protein kinase $\mathrm{B}(\mathrm{Akt})$ signaling [31]. This signaling is a possible downstream signal of the ANG II and endothelin-1 $[143,144]$. There is a controversy on the role of NOS in the stretchinduced spark enhancement in ventricular myocytes. Some researchers have reported that the blockades of NOS, stretch-activated ion channel, mitochondrial uncoupling do not suppress axial stretch-induced spark enhancement in ventricular myocytes [14].

High shear stress, associated with volume overload, mitral regurgitation and increased afterload, also significantly increased ROS in rat ventricular myocytes through NOX2 [15]. In this shear stress response, a small level of ROS generated via NOX2, in turn, induces bulk mitochondrial ROS generation, which is distinct from the source of ROS in the stretch response of ventricular myocytes [14]. The shear-induced ROS generation enhances resting $\mathrm{Ca}^{2+}$ sparks, depolarization-induced $\mathrm{Ca}^{2+}$ releases, and $\mathrm{SR} \mathrm{Ca}^{2+}$-loading. This response also involves an increase of NOS and $\mathrm{Na}^{+}-\mathrm{Ca}^{2+}$ exchanger activity in the prolonged shear stress 
stimulus [15]. It is still unclear how this shear response plays a role in the pathogenesis of ventricular muscle under pressure- or volume-overload.

In fact, volume- and pressure-overload, associated with hypertension, valvular heart diseases, and heart failure, are clinically associated with atrial fibrillation [145]. Although cellular mechanisms for the mechanical signaling in cardiac myocytes and their clear relevance to specific diseases remain to be fully understood, ROS appears to be a common effector molecule to induce cardiac myocyte remodeling and altered cardiac function. Increased afterload in the transverse aortic constriction (TAC) animal model elicited ROS increase in cardiac cells. The ROS signaling plays a critical role in the alteration of $\mathrm{Ca}^{2+}$ signaling and contractility [146]. Activation of NOX has been suggested as a potential player in pressure-overload-induced HF. Various roles for individual NOX isoforms have been reported. In NOX2 $2^{y /-}$ mice in which pressure overload was induced by TAC, hypertrophy of the left ventricle wall was prevented. However, ROS levels in the myocardium of NOX $2^{y /-}$ mice were increased, which appears to be due to compensation by other NOX isoforms that depend on $\mathrm{p} 22^{\mathrm{phox}}$ and $\mathrm{p} 47^{\mathrm{phox}}$ [147]. ANG II-induced oxidative stress was abrogated in NOX2 $2^{y /-}$ mice, ROS levels were unchanged after TAC in NOX2 $2^{\mathrm{f}-}$. Using cardiac-specific NOX4 ${ }^{-1-}$ mice, it was demonstrated that ROS production under baseline condition is reduced and that after TAC (4 weeks), these mice showed attenuated left ventricular hypertrophy. However, a contrasting finding has been reported using NOX $4^{-1-}$ mice and a cardiac NOX4 is overexpressing transgenic model. TAC and MI increased NOX4 expression, but NOX4 $4^{-/-}$mice showed larger cardiac dilatation and contractile dysfunction compared with wild-type (WT) mice, and NOX4 transgenic mice developed less hypertrophy and fibrosis compared with WT mice [148].

\section{Exogenous Natural Antioxidants to Protect Cardiac Muscle from Oxidative Stress}

\subsection{Flavonoids}

Flavonoids are a group of polyphenolic compounds diverse in chemical structure and characteristics. Flavonoids are classified into four predominant classes, 4-oxoflavonoids (flavones and flavonols), isoflavones, anthocyanins, and flavan-3-ol derivatives (tannins and catechin) $[149,150]$. They are well-known as antioxidants, free radical scavengers, and chelators of divalent cation [151,152]. SR $\mathrm{Ca}^{2+}$-ATPase pumps are known to be inhibited by various hydrophobic molecules that can be derived from natural products, such as thapsigargin [153], curcumin [154], and the flavonoid quercetin [155]. Some flavonoids can bind to nucleotide-binding sites of the SR $\mathrm{Ca}^{2+}$-ATPase pump and change its activity, which can result in apoptosis via increased cytosolic $\mathrm{Ca}^{2+}$ level and initiation of $\mathrm{Ca}^{2+}$-dependent mitochondrial pathway [156].

Catechin $\left[(2 \mathrm{R}, 3 \mathrm{~S})-3^{\prime}, 4^{\prime}, 5,7\right.$-tetrahydroxyflavan-3-ol] has been proven to effectively suppress lipid peroxidation and scavenge free radicals $[157,158]$. Several previous reports have shown that green tea (Camellia sinensis) containing catechin (specifically epigallocatechin3-gallate (EGCG)) has a cardioprotective effect $[159,160]$. It has been shown that EGCG protects I-R-induced cardiac myocytes apoptosis by decreasing phosphorylation of STAT-1, which is a transcription factor involved in the promotion of apoptosis [161,162]. Sheng et al. [163] have also shown that EGCG inhibits cardiac myocytes apoptosis and oxidative stress in pressure overload-induced hypertrophic hearts [162]. Luteolin $\left(3^{\prime}, 4^{\prime}, 5^{\prime}\right.$, $7^{\prime}$-tetrahydroxyflavone), one of the most prevalent flavones, is known to inhibit apoptosis by upregulating Akt in a simulated I-R model [163]. It also increases Bcl-2 expression and the Bcl-2 to Bax ratio and reduces Bax expression. The SERCA2a activity has been shown to be improved by luteolin via the activation of the $\mathrm{PI}(3) \mathrm{K} / \mathrm{Akt}$ signaling pathway with an increase of phosphorylated Akt. Luteolin does not seem to change the expression of SERCA2a at the protein level [164]. In adult rat cardiac myocytes, luteolin is known to improve contractile function and reduce apoptosis after I-R injury [165].

Quercetin (2-(3,4-dihydroxyphenyl)-3,5,7-trihydroxy-4H-chromen-4-one) is one of the most abundant dietary flavonoids, and it contains a polyphenolic chemical substructure that prevents oxidation in the oxidative chain reactions by scavenging free radicals, thereby 
preventing inflammation, hypertension and ischemic heart diseases [166,167]. It is known to protect cardiac myocytes from myocardial injury under doxorubicin treatment. This substance also reduces ROS generation and increases the endogenous antioxidant enzymes and non-enzymes (see above) [168]. Santos et al. [169] have shown that quercetin increases $\mathrm{I}_{\mathrm{Ca}}$ under $\beta$-adrenoceptor stimulation and intracellular $\mathrm{Ca}^{2+}$ transient without changing $\mathrm{Ca}^{2+}$ sparks [112]. Anthocyanins are a water-soluble pigment subgroup mainly found in flavonoid groups that are ranging from red to blue colors in many kinds of plants, flowers, and seeds, etc. [169]. The strength of antioxidation among anthocyanins is controlled by their differences in chemical structure, such as the number and location of conjugation groups, hydroxyl groups, glycosylation, donor electrons in the ring structure, as well as the aromatic group's capacity to sustain the disappearance of electrons $[170,171]$. Shaughnessy et al. [172] have shown that systolic blood pressure can be decreased by a blueberryenriched diet in spontaneously hypertensive stroke-prone rats [172]. Other previous studies also have shown that consumption of blueberries-containing food can suppress hypertension and prevent cardiovascular disease. The blueberries diet has been suggested to alter aortic contractility via modulation of the NO metabolic pathway. Other reports suggest that its vasodilator effect is dependent on the endothelium [173-176].

Honey from honeybee (Apis mellifera) contains acacetin and kaempferol that are effective in the heart. Acacetin (a $4^{\prime}$-O-methylated flavone), a radical scavenging flavonoid, inhibits ultrarapid delayed rectifier $\mathrm{K}^{+}$current and prolongs action potential duration in human atrial myocytes [177]. It also blocks the acetylcholine-activated $\mathrm{K}^{+}$current in guinea-pig cardiac myocytes [177]. Based on these mechanisms, acacetin has been suggested as an atrium-specific anti-atrial-fibrillation agent. It is known that kaempferol, 3,4',5,7-tetrahydroxyflavone, inhibits endothelial dysfunction and activation, resulting in reductions of cardiac fibrosis and left ventricular diastolic dysfunction in pathological condition of ANG II infusion [178]. In addition, this can protect cardiac cell apoptosis caused by I-R injury [179]. Rutin, also called rutoside and sophorin, is the glycoside combining the flavonol quercetin and the disaccharide rutinose and is a citrus flavonoid found in tea (Camellia sinensis), buckwheat (Fagopyrum esculentum), tobacco (Nicotiana tabacum) and stink beans (Parkia speciosa). Rutin has cardioprotective effects under I-R injury and also decreases cardiac hypertrophy induced by ANG II via attenuating intracellular $\mathrm{Ca}^{2+}$ increase. Rutin is known to upregulate sirtuin 1 in vitro and in vivo [180-182]. It has been suggested that rutin decreases cardiomyocyte hypertrophy induced by ANG II via the suppression of an increase of intracellular $\mathrm{Ca}^{2+}$ level [183].

Isorhamnetin, an O-methylated flavonol found in the Chinese herb Hippophae rhamnoides L., has suppressed cardiac hypertrophy by blocking the PI3K-Akt pathway [184]. In H9c2 cardiac cells, isorhamnetin has been shown to protect I-R injury by decreasing apoptosis and oxidative stress [185]. In the same cardiac cell line, this compound also has reduced ROS level, inactivated extracellular signal-regulated kinase (ERK) and inhibited $\mathrm{H}_{2} \mathrm{O}_{2}-$ induced intrinsic apoptotic pathway [186]. Rhamnetin (O-methylated flavonol) from spiraea has cardioprotective effects in miconazole-stimulated H9c2 cardiac cells through ROS reduction [187] and in ischemia-induced cardiac injury [188]. Similar cardioprotective effects have been observed with apigenin (4',5,7-trihydroxyflavone) from the flowers of chamomile. It has beneficial effects to prevent cardiac cell death under I-R injury through the PI(3)K-Akt pathway [189]. It suppresses cardiac hypertrophy and downregulates hypoxia-inducible factors in rats [190].

Baicalein (5,6,7-trihydroxyflavone) from the root of Scutellaria baicalensis Georgi [191] alleviates E3 ubiquitin-protein kinase (MARCH5) expression to inhibit apoptosis caused by oxidative stress in cardiac myocytes [192,193]. In addition, it has been reported that it protects cardiac hypertrophy in mice through initiating autophagy and repressing oxidative stress [194]. It is shown that baicalein suppresses the lipopolysaccharide-induced NO production in RAW 264.7 mouse macrophages in vitro [195] and reduced plasma NO levels leading to improved vasoreactivity, blood pressure, and survival rate in septic rats [196]. Lee and colleagues investigated the protective effect of baicalein related to HO-1 
against myocardial dysfunction caused by lipopolysaccharide-induced endotoxemia in rats [197]. According to this study, baicalein seems to improve myocardial contractility in lipopolysaccharide-induced sepsis, which may be related to reductions in oxidative stress by induction of HO-1 protein and suppression of superoxide anion formation.

Silymarin, a standardized extract of the milk thistle seeds containing a mixture of flavonolignans, can decrease abnormal growth of cardiac myocytes via downregulation of epidermal growth factor [198]. Naringin, a flavanone-7-O-glycoside, contained in Drynaria fortune, Citrus aurantium L. and Citrus medica L., is known to protect cardiac myocytes against hyperglycemia-induced injuries in vitro and in vivo [199]. It ameliorates hypoxia/reoxygenation-induced ER stress-mediated apoptosis in H9c2 cells via activating transcription factor 6 (ATF6), inositol-requiring enzyme1 $\alpha$ (IRE1 $\alpha$ ) and ERK signaling activation [200]. A previous report has shown that naringin improves mitochondrial function and reduces cardiac damage following I-R injury via the AMP-activated protein kinase (AMPK)-sirtuin 3 signaling pathway [201].

Figure 1 shows a summary on effective substances and mechanisms to decrease or increase ROS level and functional outcomes of redox unbalance in cardiac myocytes and heart.

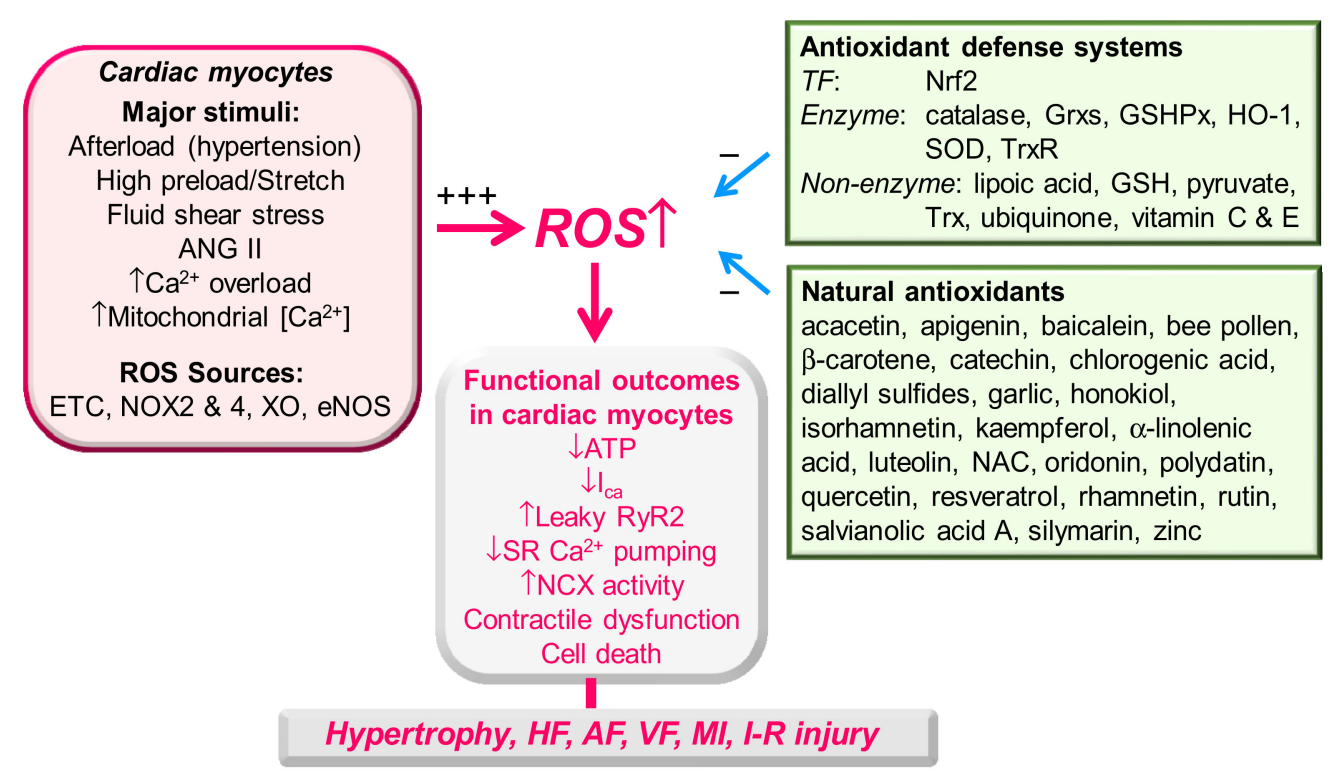

Figure 1. Effective substances and mechanisms to decrease or increase ROS level and functional outcomes of redox unbalance in cardiac myocytes and heart. Redox unbalances by overproduction of ROS via fewer antioxidants or excess ROS-producing stimuli may result in dysregulation of $\mathrm{Ca}^{2+}$ signaling and metabolism ("functional outcomes") and are associated with the pathogenesis of cardiac diseases. ETC., electron transport chain; $\mathrm{NCX}, \mathrm{Na}^{+}-\mathrm{Ca}^{2+}$ exchanger; $\mathrm{XO}$, xanthine oxidase.

\subsection{Non-Flavonoids}

$\mathrm{N}$-acetylcysteine (NAC) is a popular antioxidant that possesses a sulfhydryl group, which acts as a source of cysteine to glutathione synthesis and is used as a generic medication to treat acetaminophen overdose. It is contained in onion (Allium cepa). This compound is commonly used in the research laboratory to decrease ROS levels and test its role in biological responses. In the rat ventricular myocytes, it has been shown that NAC slightly suppresses resting $\mathrm{Ca}^{2+}$ spark occurrence [15]. In pressure-overloaded rats, NAC has suppressed myocardial fibrosis during the transition from compensated left ventricular hypertrophy to HF [202]. Myocardial total glutathione level appears to be upregulated by NAC treatment, while mitogen-activated protein kinase (MAPK) signaling is downregulated by NAC [202].

Zinc is an essential mineral largely contained in meats and oysters that is required for various cellular functions, and it has a critical antioxidant action. Metallothionein 
$\left(\mathrm{Zn}^{2+}\right.$-binding protein) expression increases at the sites of cardiac injury, which allows local accumulation of $\mathrm{Zn}^{2+}$, thereby accelerating gene transcription and wound healing. $\mathrm{Zn}^{2+}$ insufficiency can delay this process under ischemic conditions [203-209]. It is known that $\mathrm{Zn}^{2+}$ transport into the cells is achieved by $\mathrm{Zn}^{2+}$ transporters and L-type $\mathrm{Ca}^{2+}$ channels. In addition, the $\mathrm{Zn}^{2+}$ transporters can be activated by oxidative stress. The level of cytosolic free $\mathrm{Zn}^{2+}$ increases by NO, derived from endothelial NOS [210].

Resveratrol (3,5,4'-trihydroxy-trans-stilbene) is a phytoalexin produced by several plants in response to injury or when the plant is under attack by pathogens. It enhances the SOD activity and eNOS activity and increases the level of glutathione [211]. Pretreatment with resveratrol from red wine (Vitis vinifera) and blueberries (Cyanococcus) is reported to reduce infarct size and both tachycardia and bradycardia after myocardial infarction [212]. Resveratrol improves cardiac function via increases of sirtuin 1 (SIRT1) activity and AMPK activity [213]. The long-term dietary supplement of resveratrol has improved ventricular systolic function as well as an atrioventricular coupling in chronic HF rats derived from permanent coronary artery ligation [214]. The cardiovascular protective effects by resveratrol also have been recently reviewed by Carrizzo et al. [167]. Polydatin, a resveratrol glucoside found in Hu-zhang (Polygonum cuspidatum) and red wine, is one of the antioxidants showing anti-inflammation and anti-platelet coagulation. This compound can increase cardiac contraction $[215,216]$ and also has a cardioprotective effect against I-R injury and pressure-overload-induced ventricular remodeling [184]. In rat cardiac myocytes, SOD, NOS and NO were upregulated by polydatin [185]. A more recent study has shown that polydatin suppresses $\mathrm{I}_{\mathrm{Ca}}$ and $\mathrm{Ca}^{2+}$ transients and that it increases cardiac RyR activity. This compound increases contraction by enhancing myofilament $\mathrm{Ca}^{2+}$ sensitivity via NO production [186].

Honokiol (3',5-di(prop-2-en-1-yl)[1, $1^{\prime}$-biphenyl]-2,4'-diol), a lignan isolated from the bark of magnolia trees, has the capacity to activate mitochondrial sirtuin 3 that inhibits ROS production, thereby locking cardiac hypertrophy in mice [217]. Another group also has reported that this compound improves mitochondrial function and protects against doxorubicin-induced cardiotoxicity [218]. Danshen (Salvia miltiorrhiza) component salvianolic acid $A$, a stilbenoid ((R)-3(3,4-dihydroxyphenyl)-2-((E)-3-(2-((E)-3,4-dihydroxystyryl)3,4-dihydroxyphenyl)acryloyl)oxy)propanoic acid), is reported to have inhibitory effects on ventricular fibrillation and lipid peroxidation [219]. This compound has significantly attenuated cardiac dysfunction and injury induced by isoproterenol and enhanced mitochondrial respiratory function [220]. In addition, it has shown protective effects against inflammatory injury by modulating forming MD2-TLR4-MyD88 complex and TLR4-TRAF6-NF- $\mathrm{kB}$ signaling pathway in acute MI rats [221]. This compound also suppressed L-type $\mathrm{Ca}^{2+}$ channels, contraction, and $\mathrm{Ca}^{2+}$ transients in adult rat cardiac myocytes [222].

$\alpha$-linolenic acid is normally found in seeds, nuts and oils, and has beneficial effects of decreasing the risk of cardiac arrhythmias, especially ventricular fibrillation, and protect against the risk of HF and cardiac hypertrophy [223]. Under ischemia and I-R, $\alpha$-linolenic acid can protect cardiac cells from the apoptosis process by reducing the production of specific pro-apoptotic oxidized phosphatidylcholine species. Thus, the pro-apoptotic oxidized phosphatidylcholine species are thought to be a potential target to protect the heart from ischemic damage [224]. $\beta$-carotene (a terpenoid strongly colored red-orange pigment), contained in carrots, spinach and tomatoes, has a good effect of reducing the possibility of acute MI. $\beta$-carotene can significantly reduce cell death and apoptosis induced by "advanced glycation end products", which are abundant in aged persons and in the patients with diabetes mellitus, degenerative diseases, and chronic kidney disease, and are the main cause of diabetic cardiomyopathy. In addition, a recent report demonstrated that it decreases the production of intracellular ROS, antioxidative enzyme, hyperactive ER stress and autophagy via the activation of the $\mathrm{PI}(3) \mathrm{K} / \mathrm{Akt} /$ mammalian target of rapamycin (mTOR) pathway in H9c2 cells [225].

Chlorogenic acid, the ester of caffeic acid and (-)-quinic acid found in Eucommia ulmoides, is known to be a free radical scavenger and suppress the activation of the mitogen- 
activated protein kinase kinase (MEK)/ERK signaling pathway and myocardial I-R injury in rats [226]. This substance modulates the protein-B expression in cardiac myocytes following hypoxia-reoxygenation through the ROS signaling pathway [227]. It is also known that chlorogenic acid shows cardioprotective effects via directly suppressing the activation of the NF- $\mathrm{kB}$ and c-Jun N-terminal kinase (JNK) pathway in the TAC mouse model. Therefore, this component may be useful for the prevention of HF [228].

Oridonin (7,20-epoxy-1 $\alpha, 6 \beta, 7 \alpha, 14 \mathrm{R}$-tetrahydroxy-kaur-16-en-15-one; a diterpenoid), the major active ingredient of the traditional Chinese medicinal herb Rabdosia rubescens, has been suggested to have antihypertrophic effects in cardiac muscle [229]. It has been demonstrated that oridonin treatment increases the expression of myocardial HO-1 in pressure-overloaded heart muscles and that it also limits ROS generation in these hearts with an increase of myocardial SOD and GPx [229]. Furthermore, Zhao et al. [230] have demonstrated that cinnamaldehyde, one of the main bioactive constituents isolated from Cortex cinnamomi, can ameliorate cardiac dysfunction induced by lipopolysaccharides in rats through suppression of TLR4-NOX4 signaling, ROS production, and autophagy.

Bee pollen, a substance packed by worker honey bees during collection, is obtained from field-gathered flower pollen and honey, agglutinated into pellets with bee saliva. It comprises proteins, simple sugars, minerals and vitamins, and fatty acids. Due to the numerous bioactive compounds, bee pollen has been reported to have many pharmacological properties, including antioxidative effects [231-234]. According to Zhang et al.'s study, Schisandra chinensis bee pollen extract (SCBPE) possesses the most robust total antioxidant capacity among ten kinds of bee pollens, evaluated by radical scavenging activity, Trolox equivalent antioxidant capacity, and reducing power [235]. The cardioprotective effect of SCBPE against ROS attack also has been demonstrated in animal model experiments. Shen et al. [231] studied the changes in the expression of Nrf2 and HO-1 proteins by SCBPE in cardiac tissues of rat MI model induced by isoproterenol. After administrating SCBPE to rats for 30 days, the protein expression of Nrf2, HO-1, and Bcl2 (apoptosis regulator) in the heart increased in the SCBPE groups, while Bax protein (apoptotic activator) and pathological cardiac phenotype were reduced compared to the control group [231].

Garlic (Allium sativum) is widely known as a natural product with plenty of beneficial effects, such as antioxidative [236], antibacterial [237], lipid-lowering [238], and antitumor [239] activity. Notably, it is getting more attention for its powerful cardioprotective effects [236]. The organosulfur compounds are the primary active ingredients in garlic. Diallyl sulfide (DAS), diallyl disulfide (DADS), and diallyl trisulfide (DATS) have been studied, and their antioxidative effects are more substantial with a higher number of sulfur atoms (DATS > DADS > DAS) $[240,241]$. In Yu et al.'s study, DATS treatment markedly improved left ventricular systolic pressure and reduced myocardial infarct size, serum creatine kinase, lactate dehydrogenase activities, and the myocardial apoptosis in type 1 diabetic rats. They showed that these effects were partly due to the activation of the Nrf2/HO-1 antioxidant signaling pathway [242].

Table 1 categorizes natural antioxidants according to their target diseases in the heart, and summarizes their effects and action mechanisms.

Table 1. Exogenous natural antioxidants to modulate cardiac function and pathogenesis.

\begin{tabular}{|c|c|c|c|c|}
\hline Cardiac Disease & Antioxidant & Source & Effects/Mechanisms & References \\
\hline \multirow{4}{*}{ Arrhythmias } & Acacetin & Honey & Anti-AF, $\downarrow I_{\text {Kur }}$ & [177] \\
\hline & $\alpha$-Linolenic acid & Seed, nut, and their oil & Anti-VF, Anti-HF & [223] \\
\hline & Resveratrol & Red wine, blueberry & Anti-arrhythmias & [212] \\
\hline & Salvianolic acid A & Danshen & Anti-VF & [221] \\
\hline
\end{tabular}


Table 1. Cont.

\begin{tabular}{|c|c|c|c|c|}
\hline Cardiac Disease & Antioxidant & Source & Effects/Mechanisms & References \\
\hline \multirow{6}{*}{$\begin{array}{l}\text { HF/Contractile } \\
\text { dysfunction }\end{array}$} & Polydatin & $\begin{array}{c}\text { Hu zhang } \\
\text { (polygonum cuspidatum) }\end{array}$ & $\begin{array}{c}\downarrow \mathrm{I}_{\mathrm{Ca}}, \uparrow \mathrm{RyR} \text { activity, } \\
\uparrow \text { Myofilament } \mathrm{Ca}^{2+} \text { sensitivity }\end{array}$ & {$[186,215,216]$} \\
\hline & Quercetin & Oak, blueberry & $\downarrow \mathrm{I}_{\mathrm{Ca}}, \uparrow \mathrm{Ca}^{2+}$ transient & [112] \\
\hline & Luteolin & Celery, parsley & $\uparrow$ Contraction, $\uparrow$ SERCA & [165] \\
\hline & NAC & Onion & $\downarrow \mathrm{HF}$ & [202] \\
\hline & Resveratrol & Red wine, blueberry & $\uparrow$ Contraction & [214] \\
\hline & Salvianolic acid A & Danshen & $\downarrow \mathrm{I}_{\mathrm{Ca}}, \mathrm{Ca}^{2+}$ transient, contraction & [222] \\
\hline \multirow{8}{*}{ Hypertrophy } & Rutin & Tea, buckwheat, tobacco & $\downarrow$ Intracellular $\mathrm{Ca}^{2+}$ & [183] \\
\hline & NAC & Onion & $\downarrow \mathrm{MAPK}$ & [202] \\
\hline & $\alpha$-Linolenic acid & Seeds, nuts, and their oils & $?$ & [223] \\
\hline & Silymarin & Milk thistle & $\downarrow$ EGFR & [194] \\
\hline & Honokiol & Magnolia tree bark & $\uparrow$ Mitochondrial sirtuin 3 & [217] \\
\hline & Isorhamnetin & Hippophae rhamnoides L. & $\downarrow$ PI3K-Akt & [184] \\
\hline & Apigenin & Chamomile & $?$ & [190] \\
\hline & Oridonin & Rabdosia rubescens & $?$ & [229] \\
\hline \multirow{18}{*}{$\begin{array}{l}\text { MI } \\
\text { I-R injury }\end{array}$} & $\begin{array}{l}\text { Resveratrol } \\
\text { Polydatin }\end{array}$ & $\begin{array}{c}\text { Red wine, blueberry } \\
\text { Hu-zhang }\end{array}$ & $\begin{array}{l}\uparrow A M P K-s i r t u i n ~ 1, \\
\downarrow \text { apoptosis }\end{array}$ & {$[184,213]$} \\
\hline & Luteolin & Celery, parsley & $\uparrow A k t, \downarrow$ apoptosis & [163] \\
\hline & $\beta$-carotene & Carrots, spinach, tomatoes & $\uparrow p$-Akt, $\downarrow$ apoptosis & [225] \\
\hline & EGCG/catechin & Green tea & $\downarrow$ p-STAT- $1, \downarrow$ apoptosis & {$[161,162]$} \\
\hline & Kaempferol & Honey & $\downarrow$ Inflammation & [179] \\
\hline & Quercetin & Oak, blueberry & $\downarrow$ Inflammation & {$[166,167]$} \\
\hline & $\begin{array}{l}\text { Isorhamnetin } \\
\text { Rhamnetin }\end{array}$ & $\begin{array}{l}\text { Hippophae rhamnoides L. } \\
\text { Spiraea }\end{array}$ & $\begin{array}{c}\downarrow \text { ROS, } \downarrow \text { ERK } \\
\downarrow \text { ROS }\end{array}$ & {$[185,187,188]$} \\
\hline & Apigenin & Chamomile & $\uparrow \mathrm{PI} 3 \mathrm{~K}-\mathrm{Akt}$ & [189] \\
\hline & \multirow{2}{*}{ Chlorogenic acid } & \multirow{2}{*}{ Eucommia ulmoides } & $\downarrow M E K / E R K$ & [209] \\
\hline & & & Protein B & {$[210]$} \\
\hline & \multirow{2}{*}{ Rutin } & \multirow{2}{*}{ Tea, buckwheat, tobacco } & $\downarrow \mathrm{p}-\mathrm{Akt}$ & [180-182] \\
\hline & & & $\uparrow$ Sirtuin 1 & {$[181,182]$} \\
\hline & DATS, DADS, DAS & Garlic & $\uparrow \mathrm{Nrf} 2 / \mathrm{HO}-1$ & [242] \\
\hline & Baicalin & Scutellaria baicalensis & $\begin{array}{c}\text { 个Autophagy, } \uparrow \text { MARCH5 } \\
\uparrow \mathrm{HO}-1\end{array}$ & [192-194,197] \\
\hline & Naringin & Citrus & $\begin{array}{l}\uparrow \text { ATF6-IRE1 } \alpha \text {-ERK } \\
\uparrow \text { AMPK-sirtuin } 3\end{array}$ & {$[196,197]$} \\
\hline & Zinc & Meat, oysters & $\downarrow$ Oxidation & [203-209] \\
\hline & Salvianolic acid A & Danshen & $\begin{array}{c}\downarrow \text { MD2-TLR4-MyD88, } \\
\downarrow \text { TRAF6-NF-кB }\end{array}$ & [221] \\
\hline & SCBPE & Bee pollen & $\uparrow \mathrm{Nrf2}, \mathrm{HO}-1$, and Bcl2 & [231] \\
\hline
\end{tabular}

AF, atrial fibrillation; Akt, protein kinase B; EGFR, epidermal growth factor receptor; ERK, extracellular signal-regulated kinase; HF, heart failure; $\mathrm{I}_{\mathrm{Ca}}$, L-type $\mathrm{Ca}^{2+}$ current; $\mathrm{I}_{\mathrm{Kur}}$, ultrarapid delayed rectifier $\mathrm{K}^{+}$current; I-R, ischemia-reperfusion; MEK, mitogen-activated protein kinase kinase; MI, myocardial infarction; RyR, ryanodine receptor; SCBPE, Schisandra chinensis bee pollen extract; VF, ventricular fibrillation; DAS, Diallyl sulfide; DADS, diallyl disulfide, DATS, diallyl trisulfide. "?" indicates unknown. 


\section{Conclusions}

In cardiac myocytes under physiological conditions, $\mathrm{Ca}^{2+}$ signaling on regular action potentials contributes to mitochondrial $\mathrm{Ca}^{2+}$ signal, which, in turn, regulates oxidative phosphorylation of mitochondria to produce ATP with generating a small amount of ROS. ATP, produced by the mitochondria, plays a key role in maintaining cytosolic concentrations of $\mathrm{Na}^{+}, \mathrm{Ca}^{2+}$, and $\mathrm{K}^{+}$by driving $\mathrm{Na}^{+}-\mathrm{K}^{+}$pump, $\mathrm{SR} \mathrm{Ca}{ }^{2+}$ pump and $\mathrm{Na}^{+}-\mathrm{Ca}^{2+}$ exchange during beating. This is mandatory for generating normal action potentials and subsequent $\mathrm{Ca}^{2+}$-induced $\mathrm{Ca}^{2+}$ release to trigger contraction and relaxation during each cardiac cycle that determines arterial blood pressure. Ischemia and pressure- or volume-overload induce initial cardiac hypertrophy, which is accompanied by HF and arrhythmias. It is thought that remodeling and death of cardiac myocytes by bulk ROS generation via NOX (NOX2 and NOX4) and mitochondria and by $\mathrm{Ca}^{2+}$ overload during the oxygen deprivation and mechanical stresses play key roles in contractile failure and arrhythmias. Natural antioxidants may serve as an alternative way to prevent such oxidative stress-dependent cardiac pathogenesis. Antioxidants that are effective for ischemia and reperfusion injury, associated with inflammation and apoptosis/necroptosis, have been discovered from red wine (resveratrol), fruit, such as blueberries (quercetin), herbs, including green tea (catechin), chamomile (apigenin), and Citrus plants (naringin), vegetables, such as carrot ( $\beta$-carotene), celery (luteolin), and garlic (diallyl sulfides), and buckwheat (rutin), honey (kaempferol), bee pollen extract, and medicinal plants, including Polygonum cuspidatum, Hu-zhang (polydatin), Hippophae rhamnoides (isorhamnetin), danshen (salvianolic acid A), and Eucommia ulmoides (chlorogenic acid). $\alpha$-linolenic acid in the nuts and seeds has shown anti-arrhythmic and antihypertrophic effects. Resveratrol and salvianolic acid A have anti-arrhythmic effects and cardiotonic effects in HF. Quercetin decreases $\mathrm{Ca}^{2+}$ currents and is beneficial for HF. Interesting to note is that acacetin from honey has anti-atrialfibrillation effects.

In fact, clinical investigations on the effects of natural antioxidants significantly increased in recent years, but they mostly focus on blood and vascular function. A randomized clinical trial (RCT) has indirectly shown that oral supplementation of resveratrol in patients with stable angina may be cardioprotective because it decreases the inflammatory marker, brain natriuretic peptide and lipid marker $[243,244]$. The RCT recently demonstrated that quercetin has beneficial effects on blood pressure, blood lipids and endothelial function [245]. In addition, chlorogenic acid and its physiological metabolites improved human vascular functions [246]. Supplementation with green tea catechin extract or $\alpha$ linolenic acid significantly reduced circulating total cholesterol concentrations $[247,248]$. The RCTs investigating the effects of flavonoid-rich foods on cardiovascular function have shown that most compounds, except pro-anthocyanidins, are extensively metabolized and display poor bioavailability [245,249]. Nevertheless, it was recently suggested that flavonoid metabolites could be more bioactive than their precursors [245]. Further in vivo research and clinical trials need to be initiated to further validate the cardio-effective natural antioxidants in medicinal applications for cardiac hypertrophy, atrial fibrillation, MI and congestive HF.

Author Contributions: Writing—original draft preparation, S.-H.W., J.-C.K., N.E., T.-N.T., and L.N.H.D.; writing - review and editing, S.-H.W., T.-N.T., and J.-C.K. All authors have read and agreed to the published version of the manuscript.

Funding: This research was funded by National Research Foundation funded by the Korean Government (No. 2017R1E1A1A01074504).

Conflicts of Interest: The authors declare no conflict of interest.

\section{References}

1. Halliwell, B.; Gutteridge, J.M.C. Free Radicals in Biology and Medicine, 3rd ed.; Clarendon Press: Oxford, UK, 1999.

2. Senoner, T.; Dichtl, W. Oxidative stress in cardiovascular diseases: Still a therapeutic target? Nutrients 2019, 11, 2090. [CrossRef] 
3. Halliwell, B.; Gutteridge, J.M.C.; Cross, C.E. Free radicals, antioxidants, and human disease: Where are we now? J. Lab. Clin. Med. 1992, 119, 598-620.

4. Sies, H. Oxidative stress: From basic research to clinical application. Am. J. Med. 1991, 91, 31-38. [CrossRef]

5. Riley, P.A. Free radicals in biology: Oxidative stress and the effects of ionizing radiation. Int. J. Radiat Biol. 1994, 65, 27-33. [CrossRef]

6. Murphy, E.; Ardehali, H.; Balaban, R.S.; DiLisa, F.; Dornll, G.W.; Kitsis, R.N.; Otsu, K.; Ping, P.; Rizzuto, R.; Sack, M.N.; et al. Mitochondrial Function, Biology, and Role in Disease: A Scientific Statement From the American Heart Association. Circ. Res. 2016, 118, 1960-1991. [CrossRef]

7. Santulli, G.; Xie, W.; Reiken, S.R.; Marks, A.R. Mitochondrial calcium overload is a key determinant in heart failure. Proc. Natl. Acad. Sci. USA 2015, 112, 11389-11394. [CrossRef] [PubMed]

8. Gong, G.; Liu, X.; Wang, W. Regulation of metabolism in individual mitochondria during excitation-contraction coupling. J. Mol. Cell. Cardiol. 2014, 76, 235-246. [CrossRef] [PubMed]

9. Doenst, T.; Pytel, G.; Schrepper, A.; Amorim, P.; Färber, G.; Shingu, Y.; Mohr, F.W.; Schwarzer, M. Decreased rates of substrate oxidation ex vivo predict the onset of heart failure and contractile dysfunction in rats with pressure overload. Cardiovasc. Res. 2010, 86, 461-470. [CrossRef]

10. Hollander, J.M.; Thapa, D.; Shepherd, D.L. Physiological and structural differences in spatially distinct subpopulations of cardiac mitochondria: Influence of cardiac pathologies. Am. J. Physiol. Heart Circ. Physiol. 2014, 307, H1-H14. [CrossRef]

11. Zorov, D.B.; Filburn, C.R.; Klotz, L.O.; Zweier, J.L.; Sollott, S.J. Reactive oxygen species (ROS)-induced ROS release: A new phenomenon accompanying induction of the mitochondrial permeability transition in cardiac myocytes. J. Exp. Med. 2000, 192, 1001-1014. [CrossRef] [PubMed]

12. Hausenloy, D.J.; Yellon, D.M. Myocardial ischemia-reperfusion injury: A neglected therapeutic target. J. Clin. Investig. 2013, 123, 92-100. [CrossRef]

13. Cadenas, S.; Aragones, J.; Landazuri, M.O. Mitochondrial reprogramming through cardiac oxygen sensors in ischaemic heart disease. Cardiovasc. Res. 2010, 88, 219-228. [CrossRef]

14. Prosser, B.L.; Ward, C.W.; Lederer, W.J. X-ROS signaling: Rapid mechano-chemo transduction in heart. Science 2011, 333, 1440-1445. [CrossRef]

15. Kim, J.C.; Wang, J.; Son, M.J.; Woo, S.H. Shear stress enhances Ca ${ }^{2+}$ sparks through Nox2-dependent mitochondrial reactive oxygen species generation in rat ventricular myocytes. Biochim. Biophys. Acta Mol. Cell Res. 2017, 1864, 1121-1131.

16. Rajagopalan, S.; Kurz, S.; Munzel, T.; Tarpey, M.; Freeman, B.A.; Griendling, K.K.; Harrison, D.G. Angiotensin II-mediated hypertension in the rat increases vascular superoxide production via membrane NADH/NADPH oxidase activation. Contribution to alterations of vasomotor tone. J. Clin. Investig. 1996, 97, 1916-1923.

17. Sirker, A.; Zhang, M.; Shah, A.M. NADPH oxidases in cardiovascular disease: Insights from in vivo models and clinical studies. Basic Res. Cardiol. 2011, 106, 735-747. [CrossRef] [PubMed]

18. Bedard, K.; Krause, K.H. The NOX family of ROS-generating NADPH oxidases: Physiology and pathophysiology. Physiol. Rev. 2007, 87, 245-313. [CrossRef] [PubMed]

19. Hidalgo, C.; Sanchez, G.; Barrientos, G.; Aracena-Parks, P. A transverse tubule NADPH oxidase activity stimulates calcium release from isolated triads via ryanodine receptor type a S-glutathionylation. J. Biol. Chem. 2006, 281, 26473-26482. [CrossRef]

20. Ballinger, S.W. Mitochondrial dysfunction in cardiovascular disease. Free Radic. Biol. Med. 2005, 38, 1278-1295. [CrossRef] [PubMed]

21. Chan, S.H.; Wu, K.L.; Chang, A.Y.; Tai, M.H.; Chan, J.Y. Oxidative impairment of mitochondrial electron transport chain complexes in rostral ventrolateral medulla contributes to neurogenic hypertension. Hypertension 2009, 53, 217-227. [CrossRef] [PubMed]

22. Doughan, A.K.; Harrison, D.G.; Dikalov, S.I. Molecular mechanisms of angiotensin II-mediated mitochondrial dysfunction: Linking mitochondrial oxidative damage and vascular endothelial dysfunction. Circ. Res. 2008, 102, 488-496. [CrossRef]

23. Yin, J.X.; Yang, R.F.; Li, S.; Renshaw, A.O.; Li, Y.L.; Schultz, H.D.; Zimmerman, M.C. Mitochondria-produced superoxide mediates angiotensin II induced inhibition of neuronal potassium current. Am. J. Physiol. Cell Physiol. 2010, 298, C857-C865. [CrossRef]

24. Flores-Arredondo, J.H.; García-Rivas, G.; Torre-Amione, G. Immune modulation in heart failure: Past challenges and future hopes. Curr. Heart Fail. Rep. 2011, 8, 28-37. [CrossRef]

25. Harrison, D.G.; Guzik, T.J.; Lob, H.E.; Madhur, M.S.; Marvar, P.J.; Thabet, S.R.; Vinh, A.; Weyand, C.M. Inflammation, immunity, and hypertension. Hypertension 2011, 57, 132-140.

26. Marvar, P.J.; Lob, H.; Vinh, A.; Zarreen, F.; Harrison, D.G. The central nervous system and inflammation in hypertension. Curr. Opin. Pharmacol. 2011, 11, 156-161. [CrossRef] [PubMed]

27. Marvar, P.J.; Thabet, S.R.; Guzik, T.J.; Lob, H.E.; McCann, L.A.; Weyand, C.; Gordon, F.J.; Harrison, D.G. Central and peripheral mechanisms of T-lymphocyte activation and vascular inflammation produced by angiotensin II-induced hypertension. Circ. Res. 2010, 107, 263-270. [CrossRef]

28. Savoia, C.; Schiffrin, E.L. Inflammation in hypertension. Curr. Opin. Nephrol. Hypertens. 2006, 15, 152-158. [CrossRef] [PubMed]

29. Chan, S.H.; Tai, M.H.; Li, C.Y.; Chan, J.Y. Reduction in molecular synthesis or enzyme activity of superoxide dismutases and catalase contributes to oxidative stress and neurogenic hypertension in spontaneously hypertensive rats. Free Radic. Biol. Med. 2006, 40, 2028-2039. [CrossRef] [PubMed] 
30. Montezano, A.C.; Touyz, R.M. Reactive oxygen species and endothelial function-Role of nitric oxide synthase uncoupling and Nox family nicotinamide adenine dinucleotide phosphate oxidases. Basic Clin. Pharmacol. Toxicol. 2012, 110, 87-94. [CrossRef] [PubMed]

31. Petroff, M.G.; Kim, S.H.; Pepe, S.; Dessy, C.; Marbán, E.; Balligand, J.L.; Sollott, S.J. Endogenous nitric oxide mechanisms mediate the stretch dependence of $\mathrm{Ca}^{2+}$ release in cardiomyocytes. Nat. Cell Biol. 2001, 3, 867-873. [CrossRef] [PubMed]

32. Kinugawa, S.; Tsutsui, H.; Hayashidani, S.; Ide, T.; Suematsu, N.; Satoh, S.; Utsumi, H.; Takeshita, A. Treatment with dimethylthiourea prevents left ventricular remodeling and failure after experimental myocardial infarction in mice: Role of oxidative stress. Circ. Res. 2000, 87, 392-398. [CrossRef] [PubMed]

33. Martin-Garcia, J. Cardioprotection and Signaling Pathways; Springer: New York, NY, USA, 2011.

34. Krijnen, P.A.; Meischl, C.; Hack, C.E.; Meijer, C.J.; Visser, C.A.; Roos, D.; Niessen, H.W. Increased Nox2 expression in human cardiomyocytes after acute myocardial infarction. J. Clin. Pathol. 2003, 56, 194-199. [CrossRef]

35. Prabhu, S.D.; Frangogiannis, N.G. The Biological Basis for Cardiac Repair After Myocardial Infarction: From Inflammation to Fibrosis. Circ. Res. 2016, 119, 91-112. [CrossRef]

36. Hindi, S.M.; Shin, J.; Gallot, Y.S.; Straughn, A.R.; Simionescu-Bankston, A.; Hindi, L.; Xiong, G.; Friedland, R.P.; Kumar, A. MyD88 promotes myoblast fusion in a cell-autonomous manner. Nat. Commun. 2017, 8, 1624. [CrossRef]

37. Sharma, S.; Garg, I.; Ashraf, M.Z. TLR signalling and association of TLR polymorphism with cardiovascular diseases. Vasc. Pharmacol. 2016, 87, 30-37. [CrossRef] [PubMed]

38. Cho, Y.S.; Challa, S.; Moquin, D.; Genga, R.; Ray, T.D.; Guildford, M.; Chan, F.K. Phosphorylation-driven assembly of the RIP1-RIP3 complex regulates programmed necrosis and virus-induced inflammation. Cell 2009, 137, 1112-1123. [CrossRef] [PubMed]

39. Zhu, P.; Hu, S.; Jin, Q.; Li, D.; Tian, F.; Toan, S.; Li, Y.; Zhou, H.; Chen, Y. Ripk3 promotes ER stress-induced necroptosis in cardiac IR injury: A mechanism involving calcium overload/XO/ROS/mPTP pathway. Redox Biol. 2018, 16, 157-168. [CrossRef]

40. Mallet, R.T.; Olivencia-Yurvati, A.H.; Bünger, R. Pyruvate enhancement of cardiac performance: Cellular mechanisms and clinical application. Exp. Biol. Med. 2018, 243, 198-210. [CrossRef] [PubMed]

41. Li, Y.; Huang, T.T.; Carlson, E.J.; Melov, S.; Ursell, P.C.; Olson, J.L.; Epstein, C.J. Dilated cardiomyopathy and neonatal lethality in mutant mice lacking manganese superoxide dismutase. Nat. Genet. 1995, 11, 376-381.

42. Ardanaz, N.; Yang, X.P.; Cifuentes, M.E.; Haurani, M.J.; Jackson, K.W.; Liao, T.D.; Pagano, P.J. Lack of glutathione peroxidase 1 accelerates cardiac-specific hypertrophy and dysfunction in angiotensin II hypertension. Hypertension 2010, 55, 116-123. [CrossRef] [PubMed]

43. Chen, Z.; Chua, C.C.; Gao, J.; Chua, K.W.; Ho, Y.S.; Hamdy, R.C.; Chua, B.H. Prevention of ischemia/reperfusion-induced cardiac apoptosis and injury by melatonin is independent of glutathione peroxdiase 1. J. Pineal Res. 2009, 46, $235-241$.

44. Hu, C.; Zhang, H.; Qiao, Z.; Wang, Y.; Zhang, P.; Yang, D. Loss of thioredoxin 2 alters mitochondrial respiratory function and induces cardiomyocyte hypertrophy. Exp. Cell Res. 2018, 372, 61-72.

45. Huang, Q.; Zhou, H.J.; Zhang, H.; Huang, Y.; Hinojosa-Kirschenbaum, F.; Fan, P.; Yao, L.; Belardinelli, L.; Tellides, G.; Giordano, F.J.; et al. Thioredoxin-2 inhibits mitochondrial reactive oxygen species generation and apoptosis stress kinase-1 activity to maintain cardiac function. Circulation 2015, 131, 1082-1097.

46. Giordano, F.J. J. Oxygen, oxidative stress, hypoxia, and heart failure. J. Clin. Investig. 2005, 115, 500-508. [CrossRef]

47. Nordberg, J.; Arnér, E.S.J. Reactive oxygen species, antioxidants, and the mammalian thioredoxin system. Free Radic. Biol. Med. 2001, 31, 1287-1312. [CrossRef]

48. Gaucher, C.; Boudier, A.; Bonetti, J.; Clarot, I.; Leroy, P.; Parent, M. Glutathione: Antioxidant properties dedicated to nanotechnologies. Antioxidants 2018, 7, 62. [CrossRef]

49. Le, C.T.; Hollaar, L.; van der Valk, E.J.M.; van der Laarse, A. Buthionine sulfoximine reduces the protective capacity of myocytes to withstand peroxide-derived free radical attack. J. Mol. Cell. Cardiol. 1993, 25, 519-528. [CrossRef] [PubMed]

50. Kalinina, E.V.; Chernov, N.N.; Saprin, A.N. Involvement of thio-, peroxi-, and glutaredoxins in cellular redoxdependent processes. Biochemistry 2008, 73, 1493-1510.

51. Lu, J.; Holmgren, A. The thioredoxin antioxidant system. Free Radic. Biol. Med. 2014, 66, 75-87. [CrossRef]

52. Hanschmann, E.M.; Godoy, J.R.; Berndt, C.; Hudemann, C.; Lillig, C.H. Thioredoxins, glutaredoxins, and peroxiredoxinsmolecular mechanisms and health significance: From cofactors to antioxidants to redox signaling. Antioxid. Redox Signal. 2013, 19, 1539-1605. [CrossRef]

53. Chen, Q.M.; Maltagliati, A.J. Nrf2 as the heart of oxidative stress and cardiac protection. Physiol. Genom. 2018, 50, 77-97. [CrossRef]

54. Nguyen, T.; Nioi, P.; Pickett, C.B. The Nrf2-antioxidant response element signaling pathway and its activation by oxidative stress. J. Biol. Chem. 2009, 284, 13291-13295. [CrossRef] [PubMed]

55. Loboda, A.; Damulewicz, M.; Pyza, E.; Jozkowicz, A.; Dulak, J. Role of Nrf2/HO-1 system in development, oxidative stress response and diseases: An evolutionarily conserved mechanism. Cell. Mol. Life Sci. 2016, 73, 3221-3247. [CrossRef]

56. Elbirt, K.; Bonkovsky, H. Heme oxygenase: Recent advances in understanding its regulation and role. Proc. Assoc. Am. Physicians 1999, 111, 438-447. [CrossRef]

57. Paine, A.; Eiz-Vesper, B.; Blasczyk, R.; Immenschuh, S. Signaling to heme oxygenase-1 and its anti-inflammatory therapeutic potential. Biochem. Pharmacol. 2010, 80, 1895-1903. [CrossRef] 
58. Mackern-Oberti, J.; Obreque, J.; Méndez, G.; Lianos, C.; Kalergis, A. Carbon monoxide inhibits T cell activation in target organs during systemic lupus erythematosus. Clin. Exp. Immunol. 2015, 182, 1-13. [CrossRef]

59. Montellano, P.R. The mechanism of heme oxygenase. Curr. Opin. Chem. Biol. 2000, 4, 221-227. [CrossRef]

60. Tenhunen, R.; Marver, H.S.; Schmid, R. The enzymatic conversion of heme to bilirubin by microsomal heme oxygenase. Proc. Natl. Acad. Sci. USA 1968, 61, 748-755. [CrossRef] [PubMed]

61. Gottlieb, Y.; Truman, M.; Cohen, L.A.; Leichtmann-Bardoogo, Y.; Meyron-Holtz, E.G. Endoplasmic reticulum anchored hemeoxygenase-1 faces the cytosol. Haematologica 2012, 97, 1489-1493. [CrossRef] [PubMed]

62. Abraham, N.G.; Tsenovoy, P.L.; McClung, J.; Drummond, G.S. Heme oxygenase: A target gene for anti-diabetic and obesity. Curr. Pharm. Des. 2008, 14, 412-421. [CrossRef]

63. Stocker, R.; Yamamoto, Y.; McDonagh, A.F.; Glazer, A.N.; Ames, B.N. Bilirubin is an antioxidant of possible physiological importance. Science 1987, 235, 1043-1046. [CrossRef]

64. Stocker, R.; Glazer, A.N.; Ames, B.N. Antioxidant activity of albumin-bound bilirubin. Proc. Natl. Acad. Sci. USA 1987, 84, 5918-5922. [CrossRef]

65. Neuzil, J.; Stocker, R. Free and albumin-bound bilirubin are efficient co-antioxidants for alphatocopherol, inhibiting plasma and low density lipoprotein lipid peroxidation. J. Biol. Chem. 1994, 269, 16712-16719. [CrossRef]

66. Averilla, J.N.; Oh, J.; Kim, J.S. Carbon Monoxide Partially Mediates Protective Effect of Resveratrol Against UVB-Induced Oxidative Stress in Human Keratinocytes. Antioxidants 2019, 8, 432. [CrossRef]

67. Fabiato, A. Calcium-induced release of calcium from the cardiac sarcoplasmic reticulum. Am. J. Physiol. 1983, 245, C1-C14. [CrossRef]

68. Beuckelmann, D.J.; Wier, W.G. Mechanism of release of calcium from sarcoplasmic reticulum of guinea-pig cardiac cells. J. Physiol. 1988, 405, 233-255. [CrossRef]

69. Nabauer, M.; Callewaert, G.; Cleemann, L.; Morad, M. Regulation of calcium release is gated by calcium current, not gating charge, in cardiac myocytes. Science 1989, 244, 800-803. [CrossRef]

70. Niggli, E.; Lederer, W.J. Voltage-independent calcium release in heart muscle. Science 1990, 250, 565-568. [CrossRef] [PubMed]

71. Cheng, H.; Lederer, W.J.; Cannell, M.B. Calcium sparks: Elementary events underlying excitation-contraction coupling in heart muscle. Science 1993, 262, 740-744. [CrossRef] [PubMed]

72. Wier, W.G.; Egan, T.M.; Lopez-Lopez, J.R.; Balke, C.W. Local control of excitation-contraction coupling in rat heart cells. J. Physiol. 1994, 474, 463-471. [CrossRef] [PubMed]

73. Cannell, M.B.; Cheng, H.; Lederer, W.J. Spatial non-uniformities in $\left[\mathrm{Ca}^{2+}\right]_{\mathrm{i}}$ during excitation-contraction coupling in cardiac myocytes. Biophys. J. 1994, 67, 1942-1956. [CrossRef]

74. Shacklock, P.S.; Wier, W.G.; Balke, C.W. Local $\mathrm{Ca}^{2+}$ transients $\left(\mathrm{Ca}^{2+}\right.$ sparks) originate at transverse tubules in rat heart cells. J. Physiol. 1995, 487, 601-608. [CrossRef]

75. Parker, I.; Zang, W.J.; Wier, W.G. Ca ${ }^{2+}$ sparks involving multiple $\mathrm{Ca}^{2+}$ release sites along Z-lines in rat heart cells. J. Physiol. 1996, 497, 31-38. [CrossRef] [PubMed]

76. Negretti, N.; O'Neill, S.C.; Eisner, D.A. The relative contributions of different intracellular and sarcolemmal systems to relaxation in rat ventricular myocytes. Cardiovasc. Res. 1993, 27, 1826-1830. [CrossRef] [PubMed]

77. Bassani, J.W.; Bassani, R.A.; Bers, D.M. Relaxation in rabbit and rat cardiac cells: Species-dependent differences in cellular mechanisms. J. Physiol. 1994, 476, 279-293. [CrossRef] [PubMed]

78. Sommer, J.R.; Johnson, E.A. The ultra structure of cardiac muscle. In Handbook of Physiology, Section 2: The Cardiovascular System; Berne, R.M., Ed.; American Physiological Society: Washington, DC, USA, 1979; Volume 1, pp. 113-186.

79. Glancy, B.; Willis, W.T.; Chess, D.J.; Balaban, R.S. Effect of calcium on the oxidative phosphorylation cascade in skeletal muscle mitochondria. Biochemistry 2013, 52, 2793-2809. [CrossRef]

80. Traaseth, N.; Elfering, S.; Solien, J.; Haynes, V.; Giulivi, C. Role of calcium signaling in the activation of mitochondrial nitric oxide synthase and citric acid cycle. Biochim. Biophys. Acta 2004, 1658, 64-71. [CrossRef] [PubMed]

81. Bertero, E.; Maack, C. Calcium signaling and reactive oxygen species in mitochondria. Circ. Res. 2018, 122, 1460-1478. [CrossRef]

82. Bers, D.M. Cardiac exciatation-contraction coupling. Nature 2002, 415, 198-205. [CrossRef]

83. Williams, G.S.; Boyman, L.; Lederer, W.J. Mitochondrial calcium and the regulation of metabolism in the heart. J. Mol. Cell. Cardiol. 2015, 78, 35-45. [CrossRef]

84. Zima, A.V.; Blatter, L.A. Redox regulation of cardiac calcium channels and transporters. Cardiovasc. Res. 2006, 71, 310-321. [CrossRef] [PubMed]

85. Dedkova, E.N.; Blatter, L.A. Mitochondrial $\mathrm{Ca}^{2+}$ and the heart. Cell Calcium 2008, 44, 77-91. [CrossRef]

86. Ramesh, V.; Sharma, V.K.; Sheu, S.S.; Franzini-Armstrong, C. Structural proximity of mitochondria to calcium release units in rat ventricular myocardium may suggest a role in $\mathrm{Ca}^{2+}$ sequestration. Ann. N. Y. Acad. Sci. 1998, 853, 341-344. [CrossRef]

87. Franzini-Armstrong, C. ER-mitochondria communication. How privileged? Physiology 2007, 22, 261-268. [CrossRef] [PubMed]

88. Rice, J.J.; Jafri, M.S.; Winslow, R.L. Modeling gain and gradedness of $\mathrm{Ca}^{2+}$ release in the functional unit of the cardiac diadic space. Biophys. J. 1999, 77, 1871-1884. [CrossRef]

89. Michailova, A.; McCulloch, A. Model study of ATP and ADP buffering, transport of $\mathrm{Ca}^{2+}$ and $\mathrm{Mg}^{2+}$, and regulation of ion pumps in ventricular myocyte. Biophys. J. 2001, 81, 614-629. [CrossRef] 
90. Pacher, P.; Thomas, A.P.; Hajnóczky, G. $\mathrm{Ca}^{2+}$ marks: Miniature calcium signals in single mitochondria driven by ryanodine receptors. Proc. Natl. Acad. Sci. USA 2002, 99, 2380-2385. [CrossRef]

91. Subedi, K.P.; Kim, J.C.; Kang, M.; Son, M.J.; Kim, Y.S.; Woo, S.H. Voltage-dependent anion channel 2 modulates resting Ca ${ }^{2+}$ sparks, but not action potential-induced $\mathrm{Ca}^{2+}$ signaling in cardiac myocytes. Cell Calcium 2011, 49, 136-143. [CrossRef]

92. Rapizzi, E.; Pinton, P.; Szabadkai, G.; Wieckowski, M.R.; Vandecasteele, G.; Baird, G.; Tuft, R.A.; Fogarty, K.E.; Rizzuti, R. Recombinant expression of the voltage-dependent anion channel enhances the transfer of $\mathrm{Ca}^{2+}$ microdomains to mitochondria. J. Cell Biol. 2002, 159, 613-624. [CrossRef] [PubMed]

93. Boyman, L.; Williams, G.S.B.; Khananshvili, D.; Sekler, I.; Lederer, W.J. NCXL: The mitochondrial sodium calcium exchanger. J. Mol. Cell. Cardiol. 2013, 59, 205-213. [CrossRef]

94. Corral-Debrinski, M.; Shoffner, J.M.; Lott, M.T.; Wallace, D.C. Association of mitochondrial DNA damage with aging and coronary atherosclerotic heart disease. Mutat. Res. 1992, 275, 169-180. [CrossRef]

95. Santorelli, F.M.; Mak, S.C.; El-Schahawi, M.; Casali, C.; Shanske, S.; Baram, T.Z.; Madrid, R.E.; DiMauro, S. Maternally inherited cardiomyopathy and hearing loss associated with a novel mutation in the mitochondrial tRNA(Lys) gene (G8363A). Am. J. Hum. Genet. 1996, 58, 933-939.

96. Arbustini, E.; Diegoli, M.; Fasani, R.; Grasso, M.; Morbini, P.; Banchieri, N.; Bellini, O.; Bello, B.D.; Pilotto, A.; Magrini, G.; et al. Mitochondrial DNA mutations and mitochondrial abnormalities in dilated cardiomyopathy. Am. J. Pathol. 1998, 153, 1501-1510. [CrossRef]

97. Grad, L.I.; Sayles, L.C.; Lemire, B.D. Introduction of an additional pathway for lactate oxidation in the treatment of lactic acidosis and mitochondrial dysfunction in Caenorhabditis elegans. Proc. Natl. Acad. Sci. USA 2005, 102, 18367-18372. [CrossRef] [PubMed]

98. Neubauer, S. The failing heart: An engine out of fuel. N. Engl. J. Med. 2007, 356, 1140-1151. [CrossRef] [PubMed]

99. Lesnefsky, E.J.; Tandler, B.; Ye, J.; Slabe, T.J.; Turkaly, J.; Hoppel, C.L. Myocardial ischemia decreases oxidative phosphorylation through cytochrome oxidase in subsarcolemmal mitochondria. Am. J. Physiol. 1997, 273, H1544-H1554. [CrossRef] [PubMed]

100. Hunter, D.R.; Haworth, R.A. The $\mathrm{Ca}^{2+}$-induced membrane transition in mitochondria. I. The protective mechanisms. Arch. Biochem. Biophys. 1979, 195, 453-459. [CrossRef]

101. Di Lisa, F.; Carpi, A.; Giorgio, V.; Bernardi, P. The mitochondrial permeability transition pore and cyclophilin D in cardioprotection. Biochim. Biophys. Acta 2011, 1813, 1316-1322. [CrossRef]

102. Mikami, A.; Imoto, K.; Tanabe, T.; Niidome, T.; Mori, Y.; Takeshima, H.; Narumiya, S.; Numa, S. Primary structure and functional expression of the cardiac dihydropyridine-sensitive calcium channel. Nature 1989, 340, 230-233. [CrossRef]

103. Fearon, I.M.; Palmer, A.C.; Balmforth, A.J.; Ball, S.G.; Varadi, G.; Peers, C. Modulation of recombinant human cardiac L-type Ca ${ }^{2+}$ channel $\alpha 1 C$ subunits by redox agents and hypoxia. J. Physiol. 1999, 514, 629-637. [CrossRef]

104. Hu, H.; Chiamvimonvat, N.; Yamagishi, T.; Marban, E. Direct inhibition of expressed cardiac L-type Ca ${ }^{2+}$ channels by Snitrosothiol nitric oxide donors. Circ. Res. 1997, 81, 742-752. [PubMed]

105. Campbell, D.L.; Stamler, J.S.; Strauss, H.C. Redox modulation of L-type calcium channels in ferret ventricular myocytes. Dual mechanism regulation by nitric oxide and S-nitrosothiols. J. Gen. Physiol. 1996, 108, 277-293. [CrossRef] [PubMed]

106. Hove-Madsen, L.; Llach, A.; Bayes-Genís, A.; Roura, S.; Font, E.R.; Arís, A.; Cinca, J. Atrial fibrillation is associated with increased spontaneous calcium release from the sarcoplasmic reticulum in human atrial myocytes. Circulation 2004, 110, 1358-1363. [CrossRef] [PubMed]

107. Fischer, T.H.; Maier, L.S.; Sossalla, S. The ryanodine receptor leak: How a tattered receptor plunges the failing heart into crisis. Heart Fail. Rev. 2013, 18, 475-483. [CrossRef]

108. Xu, L.; Eu, J.P.; Meissner, G.; Stamler, J.S. Activation of the cardiac calcium release channel (ryanodine receptor) by poly-Snitrosylation. Science 1998, 279, 234-237. [CrossRef]

109. Pessah, I.N.; Kim, K.H.; Feng, W. Redox sensing properties of the ryanodine receptor complex. Front. Biosci. 2002, 7, a72-a79. [CrossRef]

110. Hidalgo, C.; Donoso, P.; Carrasco, M.A. The ryanodine receptors $\mathrm{Ca}^{2+}$ release channels: Cellular redox sensors? IUBMB Life 2005, 57, 315-322. [CrossRef]

111. Yan, Y.; Liu, J.; Wei, C.; Li, K.; Xie, W.; Wang, Y.; Cheng, H. Bidirectional regulation of $\mathrm{Ca}^{2+}$ sparks by mitochondria-derived reactive oxygen species in cardiac myocytes. Cardiovasc. Res. 2008, 77, 432-441. [CrossRef]

112. Trimm, J.L.; Salama, G.; Abramson, J.J. Sulfhydryl oxidation induces rapid calcium release from sarcoplasmic reticulum vesicles. J. Biol. Chem. 1986, 261, 16092-16098. [CrossRef]

113. Boraso, A.; Williams, A.J. Modification of the gating of the cardiac sarcoplasmic reticulum $\mathrm{Ca}^{2+}$-release channel by $\mathrm{H}_{2} \mathrm{O}_{2}$ and dithiothreitol. Am. J. Physiol. 1994, 267, H1010-H1016.

114. Marengo, J.J.; Hidalgo, C.; Bull, R. Sulfhydryl oxidation modifies the calcium dependence of ryanodine-sensitive calcium channels of excitable cells. Biophys. J. 1998, 74, 1263-1277. [CrossRef]

115. Gen, W.; Tani, M.; Takeshita, J.; Ebihara, Y.; Tamaki, K. Mechanisms of $\mathrm{Ca}^{2+}$ overload induced by extracellular $\mathrm{H}_{2} \mathrm{O}_{2}$ in quiescent isolated rat cardiomyocytes. Basic Res. Cardiol. 2001, 96, 623-629. [CrossRef] [PubMed]

116. Isaeva, E.V.; Shkryl, V.M.; Shirokova, N. Mitochondrial redox state and $\mathrm{Ca}^{2+}$ sparks in permeabilized mammalian skeletal muscle. J. Physiol. 2005, 565, 855-872. [CrossRef]

117. Goldhaber, J.I.; Liu, E. Excitation-contraction coupling in single guinea-pig ventricular myocytes exposed to hydrogen peroxide. J. Physiol. 1994, 477, 135-147. [CrossRef] [PubMed] 
118. Zima, A.V.; Blatter, L.A. Inositol-1,4,5-trisphosphate-dependent $\mathrm{Ca}^{2+}$ signalling in cat atrial excitation-contraction coupling and arrhythmias. J. Physiol. 2004, 555, 607-615. [CrossRef]

119. Mackenzie, L.; Bootman, M.D.; Laine, M.; Berridge, M.J.; Thuring, J.; Holmes, A.; Li, W.; Lipp, P. The role of inositol 1,4,5trisphosphate receptors in $\mathrm{Ca}^{2+}$ signalling and the generation of arrhythmias in rat atrial myocytes. J. Physiol. 2002, 541, 395-409. [CrossRef]

120. Kim, J.C.; Woo, S.H. Shear stress induces a longitudinal $\mathrm{Ca}^{2+}$ wave via autocrine activation of $\mathrm{P}_{2} \mathrm{Y}_{1}$ purinergic signalling in rat atrial myocytes. J. Physiol. 2015, 593, 5091-5109. [CrossRef]

121. Renard-Rooney, D.C.; Joseph, S.K.; Seitz, M.B.; Thomas, A.P. Effect of oxidized glutathione and temperature on inositol 1,4,5trisphosphate binding in permeabilized hepatocytes. Biochem. J. 1995, 310, 185-192. [CrossRef] [PubMed]

122. Kaplin, A.I.; Snyder, S.H.; Linden, D.J. Reduced nicotinamide adenine dinucleotide-selective stimulation of inositol 1,4,5trisphosphate receptors mediates hypoxic mobilization of calcium. J. Neurosci. 1996, 16, 2002-2011. [CrossRef] [PubMed]

123. Murphy, A.J. Sulfhydryl group modification of sarcoplasmic reticulum membranes. Biochemistry 1976, 15, 4492-4496. [CrossRef]

124. Morris, T.E.; Sulakhe, P.V. Sarcoplasmic reticulum $\mathrm{Ca}^{2+}$-pump dysfunction in rat cardiomyocytes briefly exposed to hydroxyl radicals. Free Radic. Biol. Med. 1997, 22, 37-47. [CrossRef]

125. Xu, K.Y.; Zweier, J.L.; Becker, L.C. Hydroxyl radical inhibits sarcoplasmic reticulum $\mathrm{Ca}^{2+}$-ATPase function by direct attack on the ATP binding site. Circ. Res. 1997, 80, 76-81. [CrossRef] [PubMed]

126. Adachi, T.; Weisbrod, R.M.; Pimentel, D.R.; Ying, J.; Sharov, V.S.; Schöneich, C.; Cohen, R.A. S-Glutathiolation by peroxynitrite activates SERCA during arterial relaxation by nitric oxide. Nat. Med. 2004, 10, 1200-1207. [CrossRef] [PubMed]

127. Nicoll, D.A.; Ottolia, M.; Lu, L.; Lu, Y.; Philipson, K.D. A new topological model of the cardiac sarcolemmal $\mathrm{Na}^{+}-\mathrm{Ca}^{2+}$ exchanger. $^{2}$ J. Biol. Chem. 1999, 274, 910-917. [CrossRef] [PubMed]

128. Reeves, J.P.; Bailey, C.A.; Hale, C.C. Redox modification of sodium-calcium exchange activity in cardiac sarcolemmal vesicles. J. Biol. Chem. 1986, 261, 4948-4955. [CrossRef]

129. Sedova, M.; Dedkova, E.N.; Blatter, L.A. Integration of rapid cytosolic $\mathrm{Ca}^{2+}$ signals by mitochondria in cat ventricular myocytes. Am. J. Physiol. Cell Physiol. 2006, 291, C840-C850. [CrossRef]

130. Bell, C.J.; Bright, N.A.; Rutter, G.A.; Griffiths, E.J. ATP regulation in adult rat cardiomyocytes: Time-resolved decoding of rapid mitochondrial calcium spiking imaged with targeted photoproteins. J. Biol. Chem. 2006, 281, 28058-28067. [CrossRef]

131. Sanchez, J.A.; Garcia, M.C.; Sharma, V.K.; Young, K.C.; Matlib, M.A.; Sheu, S.S. Mitochondria regulate inactivation of L-type Ca2+ channels in rat heart. J. Physiol. 2001, 536, 387-396. [CrossRef]

132. Zima, A.V.; Pabbidi, M.R.; Lipsius, S.L.; Blatter, L.A. Effects of mitochondrial uncoupling on Ca2+ signaling during excitationcontraction coupling in atrial myocytes. Am. J. Physiol Heart Circ. Physiol. 2013, 304, H983-H993. [CrossRef]

133. Lakatta, E.G. Cardiovascular regulatory mechanisms in advanced age. Physiol. Rev. 1993, 73, 413-467. [CrossRef]

134. Nazir, S.A.; Lab, M.J. Mechanoelectric feedback and atrial arrhythmias. Cardiovasc. Res. 1996, 32, 52-61. [CrossRef]

135. Sato, R.; Koumi, S. Characterization of the stretch-activated chloride channel in isolated human atrial myocytes. J. Membr. Biol. 1998, 163, 67-76. [CrossRef]

136. Tavi, P.; Han, C.; Weckström, M. Mechanisms of stretch-induced changes in $\left[\mathrm{Ca}^{2+}\right]_{\mathrm{i}}$ in rat atrial myocytes. Circ. Res. 1998, 83 , 1165-1177. [CrossRef] [PubMed]

137. Kamkin, A.; Kiseleva, I.; Wagner, K.D.; Bohm, J.; Theres, H.; Günther, J.; Scholz, H. Characterization of stretch-activated ion currents in isolated atrial myocytes from human hearts. Pflügers Archiv. 2003, 446, 339-346. [CrossRef]

138. Allen, D.G.; Nichols, C.G.; Smith, G.L. The effects of changes in muscle length during diastole on the calcium transient in ferret ventricular muscle. J. Physiol. 1988, 406, 359-370. [CrossRef]

139. Le Guennec, J.Y.; White, E.; Gannier, F.; Argibay, J.A.; Garnier, D. Stretch-induced increase of resting intracellular calcium concentration in single guinea-pig ventricular myocytes. Exp. Physiol. 1991, 76, 975-978. [CrossRef]

140. Allen, D.G.; Kurihara, S. The effects of muscle length on intracellular calcium transients in mammalian cardiac muscle. J. Physiol. 1982, 327, 79-94. [CrossRef]

141. Alvarez, B.V.; Pérez, N.G.; Ennis, I.L.; Camilión de Hurtado, M.C.; Cingolani, H.E. Mechanisms underlying the increase in force and $\mathrm{Ca}^{2+}$ transient that follow stretch of cardiac muscle: A possible explanation of the Anrep effect. Circ. Res. 1999, 85, 716-722. [CrossRef]

142. Cingolani, H.E.; Alvarez, B.V.; Ennis, I.L.; de Hurtado, M.C.C. Stretch-induced alkalinization of feline papillary muscle: An autocrine-paracrine system. Circ. Res. 1998, 83, 775-780. [CrossRef]

143. Clerk, A.; Sugden, P.H. Activation of protein kinase cascades in the heart by hypertrophic G protein-coupled receptor agonists. Am. J. Cardiol. 1999, 83, 64H-69H. [CrossRef]

144. Saward, L.; Zahradka, P. Angiotensin II activates phosphatidylinositol 3-kinase in vascular smooth muscle cells. Circ. Res. 1997, 81, 249-257. [CrossRef]

145. Nattel, S. New ideas about atrial fibrillation 50 years on. Nature 2002, 415, 219-226. [CrossRef] [PubMed]

146. Kuroda, J.; Ago, T.; Matsushima, S.; Zhai, P.; Schneider, M.D.; Sadoshima, J. NADPH oxidase 4 (Nox4) is a major source of oxidative stress in the failing heart. Proc. Natl. Acad. Sci. USA 2010, 107, 15565-15570. [CrossRef] [PubMed]

147. Maytin, M.; Siwik, D.A.; Ito, M.; Xiao, L.; Sawyer, D.B.; Liao, R.; Colucci, W.S. Pressure overload-induced myocardial hypertrophy in mice does not require gp91phox. Circulation 2004, 109, 1168-1171. [CrossRef] 
148. Zhang, M.; Brewer, A.C.; Schröder, K.; Santos, C.X.; Grieve, D.J.; Wang, M.; Anilkumar, N.; Yu, B.; Dong, X.; Walker, S.J.; et al. NADPH oxidase-4 mediates protection against chronic load-induced stress in mouse hearts by enhancing angiogenesis. Proc. Natl. Acad. Sci. USA 2010, 107, 18121-18126. [CrossRef]

149. Rhodes, M.J.C.; Price, K.R. Analytical problems in the study of flavonoid compounds in onions. Food Chem. 1996, 57, 113-117. [CrossRef]

150. Rocha-Guzmán, N.E.; Herzog, A.; González-Laredo, R.F.; Ibarra-Pérez, F.J.; Zambrano-Galván, G.; Gallegos-Infante, J.A. Antioxidant and antimutagenic activity of phenolic compounds in three different colour groups of common bean cultivars. Food Chem. 2007, 103, 521-527. [CrossRef]

151. Hanasaki, Y.; Ogawa, S.; Fnkui, S. The correlation between active oxygens scavenging and antioxidative effects of flavonoids. Free Radic. Biol. 1994, 16, 845-850. [CrossRef]

152. Afanas'ev, I.B.; Dorozhko, A.I.; Brodskii, A.V.; Kostyuk, V.A.; Potapovitch, A.I. Chelating and free radical scavenging mechanisms of inhibitory action of rutin and quercetin in lipid peroxidation. Biochem. Pharmacol. 1989, 38, 1763-1769. [CrossRef]

153. Wictome, M.; Michelangeli, F.; Lee, A.G.; East, J.M. The inhibitors thapsigargin and 2,5-di(tert-butyl)-1,4-benzohydroquinone favour the E2 form of the $\mathrm{Ca}^{2+}, \mathrm{Mg}^{2+}$-ATPase. FEBS Lett. 1992, 304, 109-113. [CrossRef]

154. Dyer, J.L.; Khan, S.Z.; Bilmen, J.G.; Hawtin, S.R.; Wheatley, M.; Javed, M.U.; Michelangeli, F. Curcumin: A new cell-permeant inhibitor of the inositol 1,4,5-trisphosphate receptor. Cell Calcium 2002, 31, 45-52.

155. Shoshan, V.; MacLennan, D.H. Quercetin interaction with the $\left(\mathrm{Ca}^{2+}+\mathrm{Mg}^{2+}\right)$-ATPase of sarcoplasmic reticulum. J. Biol. Chem. 1981, 256, 887-892. [CrossRef]

156. Ogunbayo, O.A.; Harris, R.M.; Waring, R.H.; Kirk, C.J.; Michelangeli, F. Inhibition of the sarcoplasmic/endoplasmic reticulum $\mathrm{Ca}^{2+}$-ATPase by flavonoids: Aquantitative structure-activity relationship study. IUBMB Life 2008, 60, 853-858. [CrossRef]

157. Yoshino, K.; Hara, Y.; Sano, M.; Tomita, I. Antioxidative effects of black tea theaflavins and thearubigin on lipid peroxidation of rat liver homogenates induced by tert-butyl hydroperoxide. Biol. Pharm. Bull. 1994, 17, 146-149. [CrossRef] [PubMed]

158. Salah, N.; Miller, N.J.; Paganga, G.; Tijburg, L.; Bolwell, G.P.; Riceevans, C. Polyphenolic flavanols as scavengers of aqueous phase radicals and as chain-breaking antioxidants. Arch. Biochem. Biophys. 1995, 322, 339-346. [CrossRef]

159. Stangl, V.; Dreger, H.; Stangl, K.; Lorenz, M.. Molecular targets of tea polyphenols in the cardiovascular system. Cardiovasc. Res. 2007, 73, 348-358. [CrossRef] [PubMed]

160. Khan, N.; Mukhtar, H. Tea polyphenols for health promotion. Life Sci. 2007, 81, 519-533.

161. Townsend, P.A.; Scarabelli, T.M.; Pasini, E.; Gitti, G.; Menegazzi, M.; Suzuki, H.; Stephanou, A. Epigallocatechin-3-gallate inhibits STAT-1 activation and protects cardiac myocytes from ischemia/reperfusion-induced apoptosis. FASEB J. 2004, 18, 1621-1623 [CrossRef]

162. Sheng, R.; Gu, Z.L.; Xie, M.L.; Zhou, W.X.; Guo, C.Y. EGCG inhibits cardiomyocyte apoptosis in pressure overload-induced cardiac hypertrophy and protects cardiomyocytes from oxidative stress in rats. Acta Pharmacol. Sin. 2007, 28, 191-201. [CrossRef]

163. Ha, T.; Hua, F.; Liu, X.; Ma, J.; McMullen, J.R.; Shioi, T. Lipopolysaccharide-induced myocardial protection against ischaemia/reperfusion injury is mediated through a PI3K/Akt-dependent mechanism. Cardiovasc. Res. 2008, 78, 546-553. [CrossRef]

164. Luo, Y.; Shang, P.; Li, D. Luteolin: A flavonoid that has multiple cardio-protective effects and its molecular mechanisms. Front. Pharmacol. 2017, 8, 692.

165. Qi, L.; Pan, H.; Li, D.; Fang, F.; Chen, D.; Sun, H. Luteolin improves contractile function and attenuates apoptosis following ischemia-reperfusion in adult rat cardiomyocytes. Eur. J. Pharmacol. 2011, 668, 201-207.

166. Jain, A.K.; Mehra, N.K.; Swarnakar, N.K. Role of Antioxidants for the Treatment of Cardiovascular Diseases: Challenges and Opportunities. Curr. Pharm. Des. 2015, 21, 4441-4455. [CrossRef]

167. Carrizzo, A.; Izzo, C.; Forte, M.; Sommella, E.; Di Pietro, P.; Venturini, E.; Ciccarelli, M.; Galasso, G.; Rubattu, S.; Campiglia, P.; et al. A Novel Promising Frontier for Human Health: The Beneficial Effects of Nutraceuticals in Cardiovascular Diseases. Int. J. Mol. Sci. 2020, 21, 8706. [CrossRef] [PubMed]

168. Chen, X.; Peng, X.; Luo, Y.; You, J.; Yin, D.; Xu, Q.; He, M. Quercetin protects cardiomyocytes against doxorubicin-induced toxicity

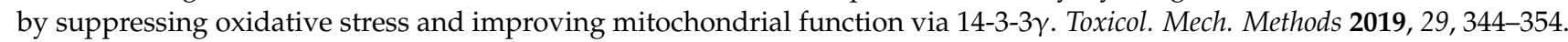

169. Santos, M.S.; Oliveira, E.D.; Santos-Miranda, A.; Cruz, J.S.; Gondim, A.N.S.; Menezes-Filho, J.E.R.; Vasconcelos, C.M.L. Dissection of the effects of quercetin on mouse myocardium. Basic Clin. Pharmacol. Toxicol. 2017, 120, 550-559.

170. Van den Hoek, T.L.; Becker, L.B.; Shao, Z.; Li, C.; Schumacker, P.T. Reactive oxygen species released from mitochondria during brief hypoxia induce preconditioning in cardiomyocytes. J. Biol. Chem. 1998, 273, 18092-18098. [CrossRef]

171. Bel, A.; Ricci, M.; Piquet, J.; Bruneval, P.; Perier, M.-C.; Gagnieu, C.; Fabiani, J.-N.; Menasché, P. Prevention of postcardiopulmonary bypass pericardial adhesions by a new resorbable collagen membrane. Interact. Cardio Vasc. Thorac. Surg. 2012, 14, 469-473. [CrossRef]

172. Shaughnessy, K.S.; Boswall, I.A.; Scanlan, A.P.; Gottschall-Pass, K.T.; Sweeney, M.I. Diets containing blueberry extract lower blood pressure in spontaneously hypertensive stroke-prone rats. Nutr. Res. 2009, 29, 130-138. [CrossRef] [PubMed]

173. Cortes, S.F.; Valadares, Y.M.; de Oliveira, A.B.; Lemos, V.S.; Barbosa, M.P.T.; Braga, F.C. Mechanism of endothelium-dependent vasodilation induced by a proanthocyanidin-rich fraction from Ouratea semiserrata. Planta Med. 2002, 68, 412-415. [CrossRef] 
174. Andriambeloson, E.; Magnier, C.; Haan-Archipoff, G.; Lobstein, A.; Anton, R.; Beretz, A.; Stoclet, J.C.; Andriantsitohaina, R. Natural dietary polyphenolic compounds cause endothelium-dependent vasorelaxation in rat thoracic aorta. J. Nutr. 1998, 128, 2324-2333. [CrossRef] [PubMed]

175. Liu, Y.; Li, D.; Zhang, Y.; Sun, R.; Xia, M. Anthocyanin increases adiponectin secretion and protects against diabetes-related endothelial dysfunction. Am. J. Physiol Endocrinol. Metab. 2014, 306, E975-E988. [CrossRef] [PubMed]

176. Luna-Vazquez, F.J.; Ibarra-Alvarado, C.; Rojas-Molina, A.; Rojas-Molina, J.I.; Yahia, E.M.; Rivera-Pastrana, D.M.; Rojas-Molina, A.; Zavala-Sánchez, M.A. Nutraceutical value of black cherry Prunus serotina Ehrh. fruits: Antioxidant and antihypertensive properties. Molecules 2013, 18, 14597-14612. [CrossRef]

177. Gui-Rong, L.; Wang, H.B.; Qin, G.W.; Jin, M.W.; Tang, Q.; Sun, H.Y.; Du, X.L.; Deng, X.L.; Zhang, X.H.; Chen, J.B.; et al. Acacetin, a Natural Flavone, Selectively Inhibits Human Atrial Repolarization Potassium Currents and Prevents Atrial Fibrillation in Dogs. Circulation 2008, 117, 2449-2457.

178. Yuan, Y.; Meng, L.; Zhou, Y.; Lu, N. Genetic polymorphism of angiotensin-converting enzyme and hypertrophic cardiomyopathy risk: A systematic review and meta-analysis. Medicine 2017, 96, e8639. [CrossRef]

179. Kim, D.S.; Ha, K.C.; Kwon, D.Y.; Kim, M.S.; Kim, H.R.; Chae, S.W.; Chae, H.J. Kaempferol protects ischemia/reperfusion-induced cardiac damage through the regulation of endoplasmic reticulum stress. Immunopharmacol. Immunotoxicol. 2008, 30, 257-270.

180. Kim, D.S.; Kwon, D.Y.; Kim, M.S.; Kim, H.K.; Lee, Y.C.; Park, S.J. The involvement of endoplasmic reticulum stress in flavonoidinduced protection on cardiac cell death caused by ischaemia/reperfusion. J. Pharm. Pharmacol. 2010, 62, 197-204. [CrossRef] [PubMed]

181. Yang, H.; Wang, C.; Zhang, L.; Lv, J.; Ni, H. Rutin alleviates hypoxia/reoxygenation-induced injury in myocardial cells by up-regulating SIRT1 expression. Chem. Biol. Interact. 2019, 297, 44-49. [CrossRef]

182. Lin, Q.; Chen, X.Y.; Zhang, J.; Yuan, Y.L.; Zhao, W.; Wei, B. Upregulation of SIRT1 contributes to the cardioprotective effect of rutin against myocardial ischemia reperfusion injury in rats. J. Funct. Foods 2018, 46, 227-236. [CrossRef]

183. Chu, J.X.; Li, G.M.; Gao, X.J.; Wang, J.X.; Han, S.Y. Buckwheat rutin inhibits Ang II-induced cardiomyocyte hypertrophy via blockade of CaN-dependent signal pathway. Iran. J. Pharm. Res. 2014, 13, 1347-1355.

184. Gao, J.P.; Chen, C.X.; Gu, W.L. Effects of polydatin on attenuating ventricular remodeling in isoproterenol-induced mouse and pressure-overload rat models. Fitoterapia 2010, 81, 953-960. [CrossRef]

185. Zhang, L.P.; Yang, C.Y.; Wang, Y.P. Protective effect of polydatin against ischemia/reperfusion injury in rat heart. Acta Physiol. Sin. 2008, 60, 161-168.

186. Deng, J.; Liu, W.; Wang, Y.; Dong, M.; Zheng, M.; Liu, J. Polydatin modulates $\mathrm{Ca}^{2+}$ handling, excitation-contraction coupling and $\beta$-adrenergic signaling in rat ventricular myocytes. J. Mol. Cell. Cardiol. 2012, 53, 646-656. [CrossRef]

187. Lee, K.P.; Kim, J.E.; Park, W.H. Cytoprotective effect of rhamnetin on miconazole-induced H9c2 cell damage. Nutr. Res. Pract. 2015, 9, 586-591.

188. Park, E.S.; Kang, J.C.; Jang, Y.C.; Park, J.S.; Jang, S.Y.; Kim, D.E.; Shin, H.S. Cardioprotective effects of rhamnetin in H9c2 cardiomyoblast cells under H2O2-induced apoptosis. J. Ethnopharmacol. 2014, 153, 552-560.

189. Zhou, Z.; Zhang, Y.; Lin, L.; Zhou, J. Apigenin suppresses the apoptosis of H9C2 rat cardiomyocytes subjected to myocardial ischemia-reperfusion injury via upregulation of the PI3K/Akt pathway. Mol. Med. Rep. 2018, 18, 1560-1570.

190. Zhu, Z.Y.; Gao, T.; Huang, Y.; Xue, J.; Xie, M.L. Apigenin ameliorates hypertension-induced cardiac hypertrophy and downregulates cardiac hypoxia inducible factor-l $\alpha$ in rats. Food Funct. 2016, 7, 1992-1998.

191. Li-Weber, M. New therapeutic aspects of flavones: The anticancer properties of Scutellaria and its main active constituents wogonin, baicalein and baicalin. Cancer Treat. Rev. 2009, 35, 57-68. [CrossRef]

192. Li, Q.; Yu, Z.; Xiao, D.; Wang, Y.; Zhao, L.; An, Y.; Gao, Y. Baicalein inhibits mitochondrial apoptosis induced by oxidative stress in cardiomyocytes by stabilizing MARCH5 expression. J. Cell. Mol. Med. 2020, 24, 2040-2051.

193. Liu, B.Y.; Li, L.; Liu, G.L.; Ding, W.; Chang, W.G.; Xu, T.; Wang, J.X. Baicalein attenuates cardiac hypertrophy in mice via suppressing oxidative stress and activating autophagy in cardiomyocytes. Acta Pharmacol. Sin. 2020, 42, 701-714. [CrossRef]

194. Cui, G.; Luk, S.C.W.; Li, R.A.; Chan, K.K.K.; Lei, S.W.; Wang, L.; Lee, S.M.Y. Cytoprotection of baicalein against oxidative stress-induced cardiomyocytes injury through the Nrf2/Keap1 pathway. J. Cardiovasc. Pharmacol. 2015, 65, 39-46.

195. Wakabayashi, I. Inhibitory effects of baicalein and wogonin on lipopolysaccharide-induced nitric oxide production in macrophages. Pharmacol. Toxicol. 1999, 84, 288-291. [CrossRef]

196. Cheng, P.Y.; Lee, Y.M.; Wu, Y.S.; Chang, T.W.; Jin, J.S.; Yen, M.H. Protective effect of baicalein against endotoxic shock in rats in vivo and in vitro. Biochem. Pharmacol. 2007, 73, 793-804. [CrossRef]

197. Lee, Y.M.; Cheng, P.Y.; Chim, L.S.; Kung, C.W.; Ka, S.M.; Chung, M.T.; Sheu, J.R. Baicalein, an active component of Scutellaria baicalensis Georgi, improves cardiac contractile function in endotoxaemic rats via induction of heme oxygenase- 1 and suppression of inflammatory responses. J. Ethnopharmacol. 2011, 135, 179-185. [CrossRef]

198. Ai, W.; Zhang, Y.; Tang, Q.; Yan, L.; Bian, Z.; Liu, C.; Huang, H.; Bai, X.; Yin, L.; Li, H. Silibinin attenuates cardiac hypertrophy and fibrosis through blocking EGFR-dependent signaling. J. Cell. Biochem. 2010, 110, 1111-1122. [CrossRef] [PubMed]

199. You, Q.; Wu, Z.; Wu, B.; Liu, C.; Huang, R.; Yang, L.; Guo, R.; Wu, K.; Chen, J. Naringin protects cardiomyocytes against hyperglycemia-induced injuries in vitro and in vivo. J. Endocrinol. 2016, 230, 197-214. [CrossRef] [PubMed] 
200. Tang, J.Y.; Jin, P.; He, Q.; Lu, L.H.; Ma, J.P.; Gao, W.L.; Bai, H.P.; Yang, J. Naringenin ameliorates hypoxia/reoxygenation-induced endoplasmic reticulum stress-mediated apoptosis in H9c2 myocardial cells: Involvement in ATF6, IRE1alpha and PERK signaling activation. Mol. Cell. Biochem. 2017, 424, 111-122. [CrossRef]

201. Yu, L.M.; Dong, X.; Xue, X.D.; Zhang, J.; Li, Z.; Wu, H.J.; Yang, Z.L.; Yang, Y.; Wang, H.S. Naringenin improves mitochondrial function and reduces cardiac damage following ischemia-reperfusion injury: The role of the AMPK-SIRT3 signaling pathway. Food Funct. 2019, 10, 2752-2765. [CrossRef] [PubMed]

202. Reyes, D.R.A.; Gomes, M.J.; Rosa, C.M.; Pagan, L.U.; Damatto, F.C.; Damatto, R.L.; Depra, I.; Campos, D.H.S.; Fernandez, A.A.H.; Martinez, P.F.; et al. N-Acetylcysteine Influence on Oxidative Stress and Cardiac Remodeling in Rats During Transition from Compensated Left Ventricular Hypertrophy to Heart Failure. Cell. Physiol. Biochem. 2017, 44, 2310-2321.

203. Singal, P.K.; Kirshenbaum, L.A. A relative deficit in antioxidant reserve may contribute in cardiac failure. Can. J. Cardiol. 1990, 6 , 47-49. [PubMed]

204. Dhaliwal, H.; Kirshenbaum, L.A.; Randhawa, A.K.; Singal, P.K. Correlation between antioxidant changes during hypoxia and recovery on reoxygenation. Am. J. Physiol. 1991, 261, H632-H638. [CrossRef] [PubMed]

205. Kirshenbaum, L.A.; Singal, P.K. Antioxidant changes in heart hypertrophy: Significance during hypoxia-reoxygenation injury. Can. J. Physiol Pharmacol. 1992, 70, 1330-1335. [CrossRef] [PubMed]

206. Sharir, H.; Zinger, A.; Nevo, A.; Sekler, I.; Hershfinkel, M. Zinc released from injured cells is acting via the $\mathrm{Zn}^{2+}$-sensing receptor, ZnR, to trigger signaling leading to epithelial repair. J. Biol. Chem. 2010, 285, 26097-26106. [CrossRef] [PubMed]

207. Iwata, M.; Takebayashi, T.; Ohta, H.; Alcalde, R.E.; Itano, Y.; Matsumura, T. Zinc accumulation and metallothionein gene expression in the proliferating epidermis during wound healing in mouse skin. Histochem. Cell Biol. 1999, 112, 283-290. [CrossRef] [PubMed]

208. Lansdown, A.B.; Sampson, B.; Rowe, A. Sequential changes in trace metal, metallothionein and calmodulin concentrations in healing skin wounds. J. Anat. 1999, 195, 375-386. [CrossRef]

209. Thomas, M.; Vidal, A.; Bhattacharya, S.K.; Ahokas, R.A.; Sun, Y.; Gerling, I.C.; Weber, K.T. Zinc dyshomeostasis in rats with aldosteronism. Response to spironolactone. Am. J. Physiol. Heart Circ. Physiol. 2007, 293, H2361-H2366. [CrossRef] [PubMed]

210. Schulz, R.; Rassaf, T.; Massion, P.B.; Kelm, M.; Balligand, J.L. Recent advances in the understanding of the role of nitric oxide in cardiovascular homeostasis. Pharmacol. Ther. 2005, 108, 225-256. [CrossRef] [PubMed]

211. Zordoky, B.N.M.; Robertson, I.M.; Dyck, J.R.B. Preclinical and clinical evidence for the role of resveratrol in the treatment of cardiovascular diseases. Biochim. Biophys. Acta 2015, 1852, 1155-1177. [CrossRef]

212. Hung, L.M.; Su, M.J.; Chen, J.K. Resveratrol protects myocardial ischemia-reperfusion injury through both NO-dependent and NO-independent mechanisms. Free Radic. Biol. Med. 2004, 36, 774-781. [CrossRef] [PubMed]

213. Gu, X.S.; Wang, Z.B.; Ye, Z.; Lei, J.P.; Li, L.; Su, D.F.; Zheng, X. Resveratrol, an activator of SIRT1, upregulates AMPK and improves cardiac function in heart failure. Genet. Mol. Res. 2014, 13, 323-335. [CrossRef]

214. Ahmet, I.; Tae, H.J.; Lakatta, E.G.; Talan, M. Long-term low dose dietary resveratrol supplement reduces cardiovascular structural and functional deterioration in chronic heart failure in rats. Can. J. Physiol. Pharmacol. 2017, 95, 268-274. [CrossRef] [PubMed]

215. Zhao, K.S.; Jin, C.; Huang, X.; Liu, J.; Yan, W.S.; Huang, Q.; Kan, W. The mechanism of polydatin in shock treatment. Clin. Hemorheol. Microcirc. 2003, 29, 211-217. [PubMed]

216. Zhao, Q.; Huang, H.X.; Jin, C.H. The regulation and its mechanism of polydatin on the $\beta$-adrenoreceptor in cardiac myocytes stimulated by lipopolysaccharide. Chin. Pharm. Bull. 2004, 20, 769-772.

217. Pillai, V.B.; Samant, S.; Sundaresan, N.R.; Raghuraman, H.; Kim, G.; Bonner, M.Y.; Gupta, M.P. Honokiol blocks and reverses cardiac hypertrophy in mice by activating mitochondrial Sirt3. Nat. Commun. 2015, 6, 1-16.

218. Huang, L.; Zhang, K.; Guo, Y.; Huang, F.; Yang, K.; Chen, L.; Yang, Q. Honokiol protects against doxorubicin cardiotoxicity via improving mitochondrial function in mouse hearts. Sci. Rep. 2017, 7, 1-12.

219. Du, G.H.; Qiu, Y.; Zhang, J.T. Protective effect of salvianolic acid a on ischemia-reperfusion induced injury in isolated rat heart. Yao Xue Xue Bao 1995, 30, 731-735.

220. Wang, S.B.; Tian, S.; Yang, F.; Yang, H.G.; Yang, X.Y.; Du, G.H. Cardioprotective effect of salvianolic acid A on isoproterenolinduced myocardial infarction in rats. Eur. J. Pharmacol. 2009, 615, 125-132.

221. Wang, X.; Guo, D.; Li, W.; Zhang, Q.; Jiang, Y.; Wang, Q.; Li, C.; Qiu, Q.; Wang, Y. Danshen (Salvia miltiorrhiza) restricts MD2/TLR4-MyD88 complex formation and signalling in acute myocardial infarction-induced heart failure. J. Cell. Mol. Med. 2020, 24, 10677-10692. [CrossRef]

222. Gao, Y.; Zhang, K.; Zhu, F.; Wu, Z.; Chu, X.; Zhang, X.; Zhang, Y.; Zhang, J.; Chu, L. Salvia miltiorrhiza (Danshen) inhibits L-type calcium current and attenuates calcium transient and contractility in rat ventricular myocytes. J. Ethnopharmacol. 2014, 158, 397-403. [CrossRef] [PubMed]

223. McLennan, P.L.; Owen, A.J.; Slee, E.L.; Theiss, M.L. Myocardial function, ischaemia and n-3 polyunsaturated fatty acids: A membrane basis. J. Cardiovasc. Med. 2007, 8, S15-S18. [CrossRef]

224. Ganguly, R.; Hasanally, D.; Stamenkovic, A.; Maddaford, T.G.; Chaudhary, R.; Pierce, G.N.; Ravandi, A. Alpha linolenic acid decreases apoptosis and oxidized phospholipids in cardiomyocytes during ischemia/reperfusion. Mol. Cell. Biochem. 2018, 437, 163-175. [CrossRef] 
225. Zhao, G.; Zhang, X.; Wang, H.; Chen, Z. Beta carotene protects H9c2 cardiomyocytes from advanced glycation end productinduced endoplasmic reticulum stress, apoptosis, and autophagy via the PI3K/Akt/mTOR signaling pathway. Ann. Transl. Med. 2020, 8, 647. [CrossRef] [PubMed]

226. Geng, J.; Zhang, Z.; Li, W. Protective effect of chlorogenic acid preconditioning on myocardial ischemia-reperfusion injury in rats. Chin. J. Mod. Appl. Pharm. 2019, 36, 682-685.

227. He, W.F.; Xue, D.Q.; Yao, L.G.; Li, J.Y.; Li, J.; Guo, Y.W. Hainanerectamines A-C, alkaloids from the Hainan sponge Hyrtios erecta. Mar. Drugs 2014, 12, 3982-3993. [CrossRef]

228. Tian, L.; Su, C.P.; Wang, Q.; Wu, F.J.; Bai, R.; Zhang, H.M.; Liu, J.Y.; Lu, W.J.; Wang, W.; Lan, F.; et al. Chlorogenic acid: A potent molecule that protects cardiomyocytes from TNF-alpha-induced injury via inhibiting NF-kappaB and JNK signals. J. Cell. Mol. Med. 2019, 23, 4666-4678. [CrossRef]

229. Xu, M.; Wan, C.X.; Huang, S.; Wang, H.; Fan, D.; Wu, H.M.; Wu, Q.; Ma, Z.; Deng, W.; Tang, Q.Z. Oridonin protects against cardiac hypertrophy by promoting P21-related autophagy. Cell Death Dis. 2019, 10, 1-16. [CrossRef]

230. Zhao, H.; Zhang, M.; Zhou, F.; Cao, W.; Bi, L.; Xie, Y.; Yang, Q.; Wang, S. Cinnamaldehyde ameliorates LPS-induced cardiac dysfunction via TLR4-NOX4 pathway: The regulation of autophagy and ROS production. J. Mol. Cell. Cardiol. 2016, 101, 11-24. [CrossRef] [PubMed]

231. Shen, Z.; Geng, Q.; Huang, H.; Yao, H.; Du, T.; Chen, L.; Wu, Z.; Miao, X.; Shi, P. Antioxidative and cardioprotective effects of Schisandra chinensis bee pollen extract on isoprenaline-induced myocardial infarction in rats. Molecules 2019, 24, 1090. [CrossRef]

232. Denisow, B.; Denisow-Pietrzyk, M. Biological and therapeutic properties of bee pollen: A review. J. Sci. Food Agric. 2016, 96, 4303-4309. [CrossRef] [PubMed]

233. Gilliam, M. Microbiology of pollen and bee bread: The yeasts. Apidologie 1979, 10, 45-53. [CrossRef]

234. Morais, M.; Moreira, L.; Feás, X.; Estevinho, L.M. Honeybee-collected pollen from five Portuguese Natural Parks: Palynological origin, phenolic content, antioxidant properties and antimicrobial activity. Food Chem. Toxicol. 2011, 49, 1096-1101. [CrossRef] [PubMed]

235. Huang, H.; Shen, Z.; Geng, Q.; Wu, Z.; Shi, P.; Miao, X. Protective effect of Schisandra chinensis been pollen extract on liver and kidney injury induced by cisplatin in rats. Biomed. Pharmacother. 2017, 95, 1765-1776. [CrossRef]

236. Ryan, E.A.; Pick, M.E.; Marceau, C. Use of alternative medicines in diabetes mellitus. Diabet. Med. 2001, 18, 242-245. [CrossRef]

237. Tessema, B.; Mulu, A.; Kassu, A.; Yismaw, G. An in vitro assessment of the antibacterial effect of garlic (Allium sativum) on bacterial isolates from wound infections. Ethiop. Med. J. 2006, 44, 385-389. [PubMed]

238. Silagy, C.; Neil, A. Garlic as a lipid lowering agent-a meta-analysis. J. R. Coll. Physicians Lond. 1994, $28,39-45$.

239. Wang, H.C.; Pao, J.; Lin, S.Y.; Sheen, L.Y. Molecular mechanisms of garlic-derived allyl sulfides in the inhibition of skin cancer progression. Ann. N. Y. Acad. Sci. 2012, 1271, 44-52. [CrossRef] [PubMed]

240. Adaki, S.; Adaki, R.; Shah, K.; Karagir, A. Garlic: Review of literature. Indian J. Cancer 2014, 51, 577-581. [CrossRef]

241. Charron, C.S.; Dawson, H.D.; Novotny, J.A. Garlic influences gene expression in vivo and in vitro. J. Nutr. 2016, 146, 444S-449S. [CrossRef]

242. Yu, L.; Li, S.; Tang, X.; Li, Z.; Zhang, J.; Xue, X.; Han, J.; Liu, Y.; Zhang, Y.; Zhang, Y.; et al. Diallyl trisulfide ameliorates myocardial ischemia-reperfusion injury by reducing oxidative stress and endoplasmic reticulum stress-mediated apoptosis in type 1 diabetic rats: Role of SIRT1 activation. Apoptosis 2017, 22, 942-954. [CrossRef] [PubMed]

243. Militaru, C.; Donoiu, I.; Craciun, A.; Scorei, I.D.; Bulearca, A.M.; Scorei, R.I. Oral resveratrol and calcium fructoborate supplementation in subjects with stable angina pectoris: Effects on lipid profiles, inflammation markers, and quality of life. Nutrition 2013, 29, 178-183. [CrossRef]

244. Del Rio, D.; Rodriguez-Mateos, A.; Spencer, J.P.; Tognolini, M.; Borges, G.; Crozier, A. Dietary (poly)phenolics in human health: Structures, bioavailability, and evidence of protective effects against chronic diseases. Antioxid. Redox Signal. 2013, 18, 1818-1892. [CrossRef] [PubMed]

245. Chiou, Y.S.; Wu, J.C.; Huang, Q.; Shahidi, F.; Wang, Y.J.; Ho, C.T.; Pan, M.H. Metabolic and colonic microbiota transformation may enhance the bioactivities of dietary polyphenols. J. Funct. Foods 2014, 7, 3-25. [CrossRef]

246. Mills, C.E.; Flury, A.; Marmet, C.; Poquet, L.; Rimoldi, S.F.; Sartori, C.; Rexhaj, E.; Brenner, R.; Allemann, Y.; Zimmermann, D.; et al. Mediation of coffee-induced improvements in human vascular function by chlorogenic acids and its metabolites: Two randomized, controlled, crossover intervention trials. Clin. Nutr. 2017, 36, 1520-1529. [CrossRef]

247. Samavat, H.; Newman, A.R.; Wang, R.; Yuan, J.M.; Wu, A.H.; Kurzer, M.S. Effects of green tea catechin extract on serum lipids in postmenopausal women: A randomized, placebo-controlled clinical trial. Am. J. Clin. Nutr. 2016, 104, 1671-1682. [CrossRef] [PubMed]

248. Yue, H.; Qiu, B.; Jia, M.; Liu, W.; Guo, X.F.; Li, N.; Xu, Z.X.; Du, F.L.; Xu, T.; Li, D. Effects of $\alpha$-linolenic acid intake on blood lipid profiles: A systematic review and meta-analysis of randomized controlled trials. Crit. Rev. Food Sci. Nutr. 2020, 9, 1-17. [CrossRef]

249. Feliciano, R.P.; Pritzel, S.; Heiss, C.; Rodriguez-Mateos, A. Flavonoid intake and cardiovascular disease risk. Curr. Opin. Food Sci. 2015, 2, 92-99. [CrossRef] 